\title{
Assessment of fish biodiversity in four Korean rivers using environmental DNA metabarcoding (\#43068)
}

Third revision

\section{Guidance from your Editor}

Please submit by $\mathbf{2 5}$ Jun $\mathbf{2 0 2 0}$ for the benefit of the authors .

\section{Structure and Criteria}

Please read the 'Structure and Criteria' page for general guidance.

\section{Author notes}

Have you read the author notes on the guidance page?

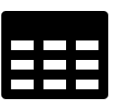

\section{Raw data check}

Review the raw data.

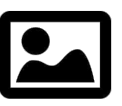

\section{Image check}

Check that figures and images have not been inappropriately manipulated.

Privacy reminder: If uploading an annotated PDF, remove identifiable information to remain anonymous.

\section{Files}

Download and review all files from the materials page.
1 Tracked changes manuscript(s)

1 Rebuttal letter(s)

8 Figure file(s)

7 Table file(s)

1 Other file(s) 


\section{Structure your review}

The review form is divided into 5 sections. Please consider these when composing your review:

\section{BASIC REPORTING}

2. EXPERIMENTAL DESIGN

3. VALIDITY OF THE FINDINGS

4. General comments

5. Confidential notes to the editor

You can also annotate this PDF and upload it as part of your review

When ready submit online.

\section{Editorial Criteria}

Use these criteria points to structure your review. The full detailed editorial criteria is on your guidance page.

\section{BASIC REPORTING}

Clear, unambiguous, professional English language used throughout.

Intro \& background to show context. Literature well referenced $\&$ relevant.

Structure conforms to Peer] standards, discipline norm, or improved for clarity.

Figures are relevant, high quality, well labelled \& described.

Raw data supplied (see Peer] policy).

\section{EXPERIMENTAL DESIGN}

Original primary research within Scope of the journal.

Research question well defined, relevant \& meaningful. It is stated how the research fills an identified knowledge gap.

Rigorous investigation performed to a high technical \& ethical standard.

Methods described with sufficient detail \& information to replicate.

\section{VALIDITY OF THE FINDINGS}

Impact and novelty not assessed.

Negative/inconclusive results accepted. Meaningful replication encouraged where rationale $\&$ benefit to literature is clearly stated.

All underlying data have been provided; they are robust, statistically sound, $\&$ controlled.
Speculation is welcome, but should be identified as such.

Conclusions are well stated, linked to original research question $\&$ limited to supporting results. 


\section{Standout \\ reviewing tips}

The best reviewers use these techniques

Tip

\section{Support criticisms with evidence from the text or from other sources}

\section{Give specific suggestions on how to improve the manuscript}

\section{Comment on language and grammar issues}

\author{
Please provide constructive \\ criticism, and avoid personal \\ opinions
}

\section{Example}

Smith et al (J of Methodology, 2005, V3, pp 123) have shown that the analysis you use in Lines 241-250 is not the most appropriate for this situation. Please explain why you used this method.

Your introduction needs more detail. I suggest that you improve the description at lines 57- 86 to provide more justification for your study (specifically, you should expand upon the knowledge gap being filled).

The English language should be improved to ensure that an international audience can clearly understand your text. Some examples where the language could be improved include lines 23, 77, 121, 128 - the current phrasing makes comprehension difficult.

1. Your most important issue

2. The next most important item

3....

4. The least important points

I thank you for providing the raw data, however your supplemental files need more descriptive metadata identifiers to be useful to future readers. Although your results are compelling, the data analysis should be improved in the following ways: $A A, B B, C C$

I commend the authors for their extensive data set, compiled over many years of detailed fieldwork. In addition, the manuscript is clearly written in professional, unambiguous language. If there is a weakness, it is in the statistical analysis (as I have noted above) which should be improved upon before Acceptance.
Comment on strengths (as well as weaknesses) of the manuscript 


\section{Assessment of fish biodiversity in four Korean rivers using environmental DNA metabarcoding}

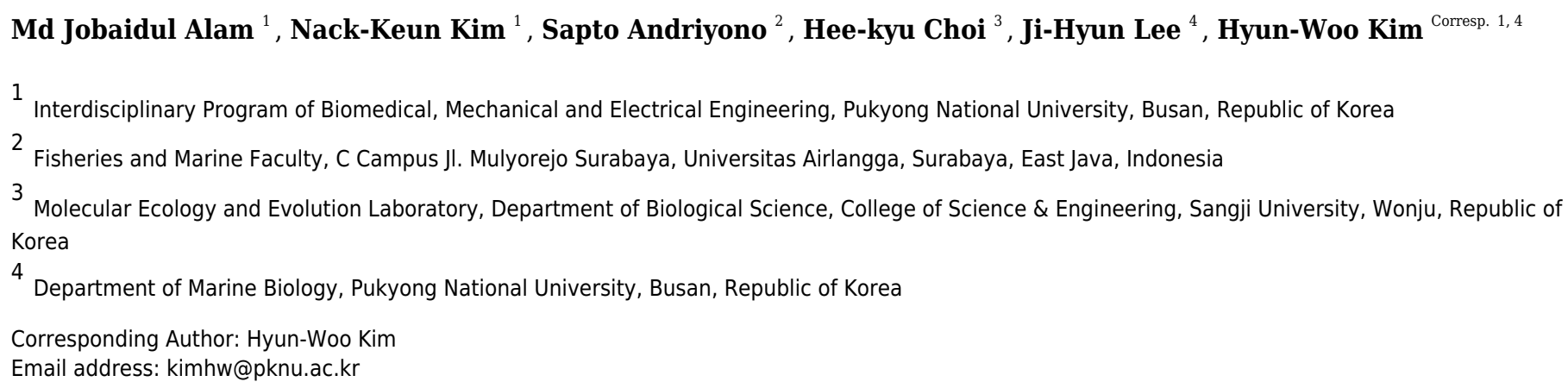

Environmental DNA (eDNA) metabarcoding is a cost-effective novel approach to estimate biodiversity in an ecosystem. In this study, the MiFish pipeline was employed to test if the system methodology is sufficiently reliable to estimate fish biodiversity in Korean rivers. A total of 125 unique haplotypes and 73 species were identified at the species level from 16 water samples collected from a single survey in four Korean rivers (Hyeongsan, Taehwa, Seomjin, and Nakdong). Among the four rivers, the highest species richness was recorded in the Seomjin River (52 species), followed by the Taehwa (42 species) and Hyeongsan (40 species) rivers. The Nakdong River (26 species) presented the lowest species richness and number of endemic species, presumably due to its metropolitan location and anthropogenic impacts, such as dams or weirs. We were also able to detect that five exotic species (Carassius cuvieri, Cyprinus carpio, Cyprinus megalophthalmus, Lepomis macrochirus, and Micropterus salmoides) are widely distributed in all surveyed rivers, a situation that might be problematic in terms of conservation. Our findings indicate that the eDNA metabarcoding technique is one of the most cost-effective scientific tools available for the management and conservation of the freshwater fish resources available in Korea. However, the low number of $12 \mathrm{~S}$ sequences of endemic species in the database and low resolution of the MiFish region for differentiating several taxa should be upgraded for their wide use. 
1 Assessment of fish biodiversity in four Korean rivers using environmental DNA 2 metabarcoding

3 Md. Jobaidul Alam ${ }^{1}$, Nack-Keun Kim ${ }^{1}$, Sapto Andriyono ${ }^{1,2}$, Hee-kyu Choi ${ }^{3}$, Ji-Hyun Lee ${ }^{4}$, and 4 Hyun-Woo Kim ${ }^{1,4 *}$

5

$6{ }^{1}$ Interdisciplinary Program of Biomedical, Mechanical and Electrical Engineering, Pukyong 7 National University, Busan, 48513, Republic of Korea

8 2Fisheries and Marine Faculty, C Campus Jl. Mulyorejo Surabaya 60115. Universitas Airlangga,

9 Surabaya, East Java, Indonesia

$10{ }^{3}$ Molecular Ecology and Evolution Laboratory, Department of Biological Science, College of 11 Science \& Engineering, Sangji University, Wonju 26339, Republic of Korea

$12{ }^{4}$ Department of Marine Biology, Pukyong National University, Busan 48513, Republic of

13 Korea

14

15

$16 *$ Corresponding author:

17 Hyun-Woo Kim, Ph. D

18

Department of Marine Biology

19 Pukyong National University

20

48513, Republic of Korea

21 Tel: 82-51-629-5926

22 Fax: 82-51-629-5930

23 E-mail:kimhw@pknu.ac.kr

24

25

26

27

Peer) reviewing PDF | (2019:11:43068:3:1:CHECK 4 Jun 2020) 


\section{ABSTRACT}

29 Environmental DNA (eDNA) metabarcoding is a cost-effective novel approach to estimate biodiversity in an ecosystem. In this study, the MiFish pipeline was employed to test if the system methodology is sufficiently reliable to estimate fish biodiversity in Korean rivers. A total of 125 unique haplotypes and 73 species were identified at the species level from 16 water samples collected from a single survey in four Korean rivers (Hyeongsan, Taehwa, Seomjin, and Nakdong). Among the four rivers, the highest species richness was recorded in the Seomjin River (52 species), followed by the Taehwa (42 species) and Hyeongsan (40 species) rivers. The Nakdong River (26 species) presented the lowest species richness and number of endemic species, presumably due to its metropolitan location and anthropogenic impacts, such as dams or weirs. We were also able to detect that five exotic species (Carassius cuvieri, Cyprinus carpio, Cyprinus megalophthalmus, Lepomis macrochirus, and Micropterus salmoides) are widely distributed in all surveyed rivers, a situation that might be problematic in terms of conservation. Our findings indicate that the eDNA metabarcoding technique is one of the most costeffective scientific tools available for the management and conservation of the freshwater fish resources available in Korea. However, the low number of $12 \mathrm{~S}$ sequences of endemic species in the database and low resolution of the MiFish region for differentiating several taxa should be upgraded for their wide use.

Keywords: biodiversity, Korea, next-generation sequencing, MiFish, metabarcoding, eDNA 
50 Fish communities have been considered as reliable bioindicators of ecosystem status due to their

51 vulnerability to environmental or anthropogenic stresses such as pollution, climate change, or

52 other disturbances in habitats (Dudgeon, 2010). Traditional monitoring methods for fish

53 biodiversity, which have relied on the direct capture or observation of specimens, are often

54 costly and time-consuming due to a lack of taxonomic expertise and the necessity of extensive

55 fieldwork. Environmental DNA (eDNA) metabarcoding (detection of multispecies by using

56 degraded DNA from environmental samples) has been proposed as an alternative strategy to

57 analyze fish biodiversity, demonstrating the potential to improve the traditional methods in a

58 cost-effective way (Foote et al., 2012; Kelly et al., 2017; Kelly et al., 2014; Shaw et al., 2016;

59 Stoeckle et al., 2017; Yamamoto et al., 2017).This technique has been shown to be sensitive as it

60 allows the identification of rarely identified (Pilliod et al., 2013), invasive (Ardura et al., 2015;

61 Cai et al., 2017; Clusa et al., 2017; Dejean et al., 2012; Klymus et al., 2017; Takahara et al., 2013;

62 Williams et al., 2018), or migratory species (Gustavson et al., 2015; Pont et al., 2018; Yamamoto

63 et al., 2016; Yamanaka and Minamoto, 2016).

64 Since eDNA metabarcoding analysis of fish biodiversity is mainly based on the amplicon of

65 homologous genes by PCR, universal primers with high taxon-specificity and wide taxon-

66 coverage are essential. Three fish-specific universal primer sets are currently reported: two sets

67 for 12S rRNA regions [EcoPrimers (Riaz et al., 2011) and MiFish (Miya et al., 2015b)] and one

68 for the 16S rRNA region (Shaw et al., 2016). Among them, the MiFish primer set demonstrated

69 reliability for eDNA metabarcoding analysis of fish biodiversity in both marine (Ushio et al.,

70 2017; Yamamoto et al., 2017) and continental waters (Sato et al., 2018). More recently, the web-

71 based MiFish pipeline in MitoFish was publicly open (http://mitofish.aori.u-tokyo.ac.jp/mifish/),

72 alleviating the time-consuming bioinformatic analysis for the users (Sato et al., 2018). 
Although metabarcoding analysis by the MiFish pipeline is one of the most reliable tools at

74

4

the moment, numbers of MiFish sequences in the database are still one of the last hurdles to overcome for the global use of the MiFish pipeline. Since the average length of the MiFish region is approximately $170 \mathrm{bp}$, which is much smaller than the typically used $670 \mathrm{bp}$ of the COI barcodes, a high-quality database is critical for successful species assignment. Species identification using the MiFish primer could not discriminate closely related species in several genera, including Sebastes spp. and Takifugu spp. (Yamamoto et al., 2017). In particular, considering the tremendous diversity of freshwater fishes, the direct application of the MiFish platform may produce a high amount of 'unidentified' records. In addition, a relatively much lower amount of MiFish sequence data (12S region) is currently deposited compared with those of the COI region. Therefore, before the direct application of the MiFish pipeline, the MiFish DNA sequence data for the local freshwater species should be tested for accurate fish biodiversity analysis using eDNA metabarcoding.

In this study, we first employed eDNA metabarcoding analysis of water samples collected from four rivers using the MiFish primer set in order to improve the knowledge regarding freshwater fish biodiversity in Korea. Next, we analyzed the haplotypes obtained by the MiFish pipeline to assess their compatibilities in the identification of endemic species of fishes inhabiting Korean rivers. We also calculated the Shannon-Wiener $\left(\mathrm{H}^{\prime}\right)$ indices derived from the eDNA metabarcoding results to estimate fish biodiversity in four Korean rivers. Finally, the relationship between the fish assemblage according to the locations in the river was analyzed using heat-map clustering analysis.

\section{MATERIALS AND METHODS}


96

97

\section{Sample collection and environmental DNA extraction}

7 The eDNA water samples were collected on June 11 and 12, 2018 from 16 stations in the Hyeongsan, Taehwa, Seomjin, and Nakdong rivers, which are four large rivers in the southern part of the Korean Peninsula (Fig.1 and Table 1). In this study, the sampling stations of each river were categorized as upstream (stations 1 and 2), midstream (station 3), and downstream (Station 4). One liter of water was collected at each station using disposable plastic bottles. After collecting the water, the bottles were immediately stored in an icebox and taken to the laboratory for filtration. Water temperature and salinity were measured with a conductivity meter (CD4307SD, LUTRON). The water collected was filtered $(250 \mathrm{~mL} \times 4)$ with a $0.45 \mu \mathrm{m}$ pore-sized GN-6 membrane (PALL Life Sciences, Mexico). The filtration system was cleaned with $10 \%$ commercial bleach containing sodium hypochlorite to prevent cross-contamination. After filtration, the membranes were put into $2.0 \mathrm{ml}$ tubes and stored at $-20{ }^{\circ} \mathrm{C}$ before DNA purification.

Genomic DNA was extracted directly from the membrane filters using the DNeasy® Blood and Tissue Kit (Qiagen, Germany), according to the manufacturer's manual. The membrane filters were cut into smaller pieces before homogenization using a TissueLyser II motorized homogenizer (QIAGEN, Hilden, Germany). The extracted genomic DNA was quantified using a ND-1000 NanoDrop (Thermo Scientific, Waltham, MA, USA), aliquoted, and stored at $-20{ }^{\circ} \mathrm{C}$.

\section{Construction of the library and MiSeq sequencing}

In order to assess the fish biodiversity, amplicon libraries of partial $12 \mathrm{~S}$ rRNA region using the MiFish universal primer sets were constructed (Miya et al., 2015a). The first PCR was performed to amplify the MiFish regions with an overhanging linker sequence for each Nextera XT index 
119 (Illumina, USA). The PCR mixture $(20 \mu \mathrm{L})$ contained $1.0 \mu \mathrm{L}$ of the MiFish (forward \& reverse)

120 primers (5pmol each), $2.0 \mu \mathrm{L}$ template, $2.0 \mu \mathrm{L}$ dNTPs $(2.5 \mathrm{mM}), 2.0 \mu \mathrm{L}$ of $10 \mathrm{X}$ EX Taq buffer,

$1210.6 \mu \mathrm{L}$ DMSO (3 \%), 0.2 $\mu \mathrm{L}$ of EXTaq Hot Start polymerase (TaKaRa Bio Inc. Japan), and

$12211.20 \mu \mathrm{L}$ ultra-pure water. The PCR reaction began with denaturation at $95^{\circ} \mathrm{C}$ for 3 min;

123 followed by 30 cycles at $94{ }^{\circ} \mathrm{C}$ for $20 \mathrm{~s}, 65^{\circ} \mathrm{C}$ for $15 \mathrm{~s}$, and $72{ }^{\circ} \mathrm{C}$ for $15 \mathrm{~s}$; and a final extension

124 at $72{ }^{\circ} \mathrm{C}$ for $5 \mathrm{~min}$. The amplicon with the expected size (250-350 bp) was purified with the

125 AccuPrep ${ }^{\circledR}$ Gel Purification Kit (Bioneer, Republic of Korea) after 1.5 \% agarose gel

126 electrophoresis. The purified amplicons were subjected to additional PCR to link each amplicon

127 with the corresponding Nextera XT index. The second PCR mixture $(20 \mu \mathrm{L})$ contained $5 \mu \mathrm{L}$

128 template, $1 \mu \mathrm{L}$ of a couple of index primers (10 pmol), $0.5 \mu \mathrm{L}$ dNTPs $(10 \mathrm{mM}), 4 \mu \mathrm{L} 5 \mathrm{X}$

129 Phusion HF Buffer, $8.3 \mu \mathrm{L}$ ultrapure water, and $0.2 \mu \mathrm{L}$ Phusion Hot Start Flex DNA polymerase

130 (New England Biolabs, Hitchen, UK). The second PCR started at $94{ }^{\circ} \mathrm{C}$ for $5 \mathrm{~min}$; followed by

13115 cycles at $94^{\circ} \mathrm{C}$ for $30 \mathrm{~s}, 55^{\circ} \mathrm{C}$ for $30 \mathrm{~s}$, and $72{ }^{\circ} \mathrm{C}$ for $30 \mathrm{~s}$; and an additional 5 min at $72{ }^{\circ} \mathrm{C}$.

132 No noticeable bands were detected in the desired ranges for 16 field negative controls in $1.5 \%$

133 agarose gel electrophoresis. Consequently, the 16 negative controls were discarded from the

134 following analyses. After gel purification, the quality and quantity of the indexed PCR products

135 with the expected sizes were analyzed using the Qubit dsDNAHS Assay Kit (Invitrogen,

136 Carlsbad, CA, USA), followed by sequencing using the MiSeq platform $(2 \times 300 \mathrm{bp})$.

137

138 Bioinformatic analysis of the NGS data

139 The MiSeq raw reads were paired using Python 2.7 (Zhang, 2015), and the paired reads were

140 uploaded to the MiFish pipeline (http://mitofish.aori.u-tokyo.ac.jp/mifish/) for further analyses.

141 In the MiFish pipeline, a low-quality tail of reads $(\mathrm{QV} \leq 20)$ was trimmed in FASTQC. After 
142 taxonomic assignments from the MiFish pipeline, the sequences assigned to OTUs were 143 compared with the GenBank database. If the sequence identity of the query sequence and top

144 BLASTN hit was $\geq 99 \%$, the sequence was ascertained as a particular species. If the sequence 145 identity ranged from $97 \%$ to $99 \%$, the sequence was ascertained to the genus level, whereas 146 sequences ranging from $97 \%$ to $95 \%$ were assigned as 'unidentified' genera. The geographic

147 distribution of each species was assessed on the FishBase website (https://www.fishbase.org/). 148 Alpha biodiversity was measured using the normalized read numbers from each sampling station 149 of the four rivers sampled. The Shannon-Wiener $\left(\mathrm{H}^{\prime}\right)$ index indicates the heterogeneity of species 150 or the richness of species in an ecosystem (Gray, 2000; Magurran, 1988). The $\mathrm{H}^{\prime}$ index and the

151 heat map clustering analysis were calculated using the PRIMER ${ }^{\circledR}$ v7 software (Clarke and 152 Gorley, 2015).

154 RESULTS

155 Physicochemical parameters

156 The water temperature of the sample sites ranged from $18.6{ }^{\circ} \mathrm{C}$ to $24.20^{\circ} \mathrm{C}$ (Table 1 ). The 157 Hyeongsan River showed the highest temperature difference $\left(5.4{ }^{\circ} \mathrm{C}\right)$ between upstream $(\mathrm{HS} 1)$ to 158 downstream (HS4), whereas the lowest levels of temperature variation were observed in the 159 Seomjin $\left(0.8^{\circ} \mathrm{C}\right)$ and Nakdong $\left(1.5^{\circ} \mathrm{C}\right)$ rivers. The lowest salinity $(0.15$ PSU) was measured at 160 station 1 (upstream) of the Seomjin River, while the highest (20.20 PSU) was recorded at station 1614 (downstream) of the Hyeongsan River. The salinity level increased from upstream to 162 downstream in all rivers, except in the Nakdong River, where an artificial dam was constructed 163 to block water from the ocean (Table 1). 
165 Analysis of fish haplotypes obtained using the MiFish pipeline

166 The reliability of the MiFish pipeline (http://mitofish.aori.u-tokyo.ac.jp/mifish/workflows/ new)

167 for the biodiversity assessment of fish species inhabiting the sampled rivers was analyzed (Table 168 2). From 2,315,605 raw reads, 2,280,850 merged reads were obtained by the MiFish pipeline,

169 with a $98.50 \%$ yield from the raw reads. A total of 238 representative haplotypes were assigned 170 to the default cutoff sequence identity. Among the 238 haplotypes, 125 unique haplotypes were 171 identified using the phylogenetic tree analysis in the MEGA 7 software (Kumar et al., 2016) with 172 a maximum likelihood algorithm (Fig. 2-5). A total of 2,241,130 reads $(98.26 \%)$ were assigned 173 to 73 confirmed species, 46 genera, and 13 families of Teleostei, with $99 \%$ as cutoff identity.

174 The remaining 39,720 reads (49 haplotypes), which showed less than $99 \%$ identity, were further 175 assigned to11 genera and eight unidentified genera (Table 3). A total of 34,755 reads (1.50\%) 176 were discarded from further analyses. The highest species number was identified in the family 177 Cyprinidae (35), followed by Gobiidae (11), and Cobitidae (8), while the remaining (19) were 178 from other families of Teleostei. Among them, the highest species number (4 species) was 179 identified in the genus Acheilognathus, followed by Carassius, Misgurnus, Squalidus, and 180 Tridentiger with three species in each of those genera (Table S1).

\section{Cyprinidae}

183 A total of 65 haplotypes were identified in the family Cyprinidae. Among the 65 haplotypes, 51 184 were assigned to 35 species of fishes with $\geq 99 \%$ of sequence identity to the GenBank database 185 (Fig. 2). Two haplotypes in the genus Hemibarbus from the Seomjin River (SJ1) and the Nakdong River (ND2) showed $100 \%$ and $99 \%$ identity to the sequences of Hemibarbus labeo

187 (GenBank Number: DQ347953) and Hemibarbus maculatus (LC146032) sampled in Korea and 
188 Japan, respectively. Among the four endemic species in the genus Hemibarbus, H. labeo and $H$. 189 longirostris are the most widely distributed species in Korea (Lee et al., 2012). Two haplotypes 190 identified from the Seomjin River (SJ1 and SJ2) and one from Taehwa River (TH1) showed $97 \%$ 191 and $95 \%$ identity to a sequence of $H$. longirostris (LC049889), respectively, which suggests that 192 these three haplotypes may be either H. longirostris or H. mylodon (Fig.2).

193 Five haplotypes were identified in the genus Squalidus. Four species of the genus have been 194 reported from Korean waters: Squalidus gracilis, S. japonicus, S. multimaculatus, and S. chankaensis (Kim and Park, 2002). Two haplotypes from the Taehwa (TH3) and Hyeongsan rivers (HS1) showed $100 \%$ identity to sequences of S. japonicas coreanus (GenBank Number: KR075134) and S. multimaculatus (GenBank Number: KT948081), respectively. Another haplotype from the Hyeongsan River (HS3) showed $100 \%$ identity to a sequence of $S$. japonicas (GenBank Number: LC277782) sampled in Japan. Two haplotypes from the Seomjin River showed $99 \%$ identity to a sequence of $S$. chankaensis tsuchigae (GenBank Number: KT948082) sampled in Korea.

Fishes of the subfamily Acheilognathinae, commonly known as bitterlings, deposit eggs in 203 the gill cavities of freshwater mussels (Kitamura, 2007; Kitamura et al., 2012). Approximately 60 species of bitterlings are considered valid in the genera Acheilognathus, Tanakia, and Rhodeus (Arai, 1988). Acheilognathus intermedia, A. macropterus, A. majusculus, A. rhombeus, Rhodeus suigensis, $R$. uyekii, Tanakia somjinensis, and T. signifier were identified with a sequence identity $>99 \%$ when compared to the GenBank database. Three haplotypes from the Seomjin River showed $99 \%$ sequence identity to the respective haplotypes of $A$. intermedia (EF483933), T. somjinensis (FJ515921), and T. signifier (EF483930) sampled in Korea. Among 
211 from the Taehwa River (TH3) showed $100 \%$ identity to a sequence of Rhynchocypris semotilus

212 (KT748874) sampled in Korea. This species is currently categorized as Critically Endangered in

213 the Red Data Book of endangered fishes in Korea (Ko et al., 2011).

214 Two sub-species of Sarcocheilichthys are known in Korea: S. nigripinnis morii and $S$.

215 variegates wakiyae (Kim and Park, 2002). Two haplotypes from the Seomjin (SJ2) and

216 Hyeongsan (HS2) rivers showed $100 \%$ and $97 \%$, respectively, identity to a sequence of $S$.

217 variegatus wakiyae (GenBank Number: KU301744) sampled in Korea. One haplotype from the

218 Hyeongsan River (HS2) showed $100 \%$ and $99.43 \%$ identity to a sequence of $S$. soldatovi

219 (LC146036) and the Korean haplotype of S. nigripinnis morii (AP017653) sampled in Japan and

220 Korea, respectively. However, S. soldatovi is not currently reported for Korean waters. Therefore,

221 further studies are needed to confirm the occurrence of this species in the Hyeongsan River for

222 conservation purposes.

223

224 Gobiidae

225 We identified 16 haplotypes of the family Gobiidae, representing seven genera and 11 species

226 (Fig. 3). Five haplotypes were identified in the genus Tridentiger, which represents the five

227 known species of the genus recorded in Korea (Kim et al., 2005). One haplotype from the

228 Taehwa River (TH4) showed $100 \%$ identity with a sequence of T. obscures (GenBank Number:

229 KT601092) sampled in Korea. One haplotype from the Hyeongsan River (HS4) showed $100 \%$

230 identity to a sequence of T. trigonocephalus (GenBank Number: LC385175) sampled in Japan,

231 and another haplotype from the Seomjin River (SJ3) showed $100 \%$ identity to a sequence of $T$.

232 trigonocephalus (GenBank Number: KM030481) sampled in Korea. According to the recovered

233 phylogenetic tree, the T. trigonocephalus haplotype from the Seomjin River is different from that 
234 of the Hyeongsan River (Fig. 3). All three haplotypes of the genus Rhinogobius showed $100 \%$

235 identity to the database. The first and second haplotypes showed $100 \%$ identity to sequences of

236 R. brunneus sampled in Korea (KM030471) and Japan (LC049760), respectively. The third

237 haplotype showed $100 \%$ identity to a sequence of $R$. giurinus sampled in Korea (KM030475).

238 Two haplotypes of Gymnogobius sp. from the Taehwa and Hyeongsan rivers showed $98 \%$

239 sequence identity to G. taranetzi (GenBank Number: LC385155). Nine species of the genus

240 Gymnogobius are currently reported in Korea (Kim et al., 2005), and their MiFish sequences

241 should be supplemented to the GenBank database.

242

243 Cobitidae

244 Sixteen species in five genera of the family Cobitidae are currently reported from Korean 245 rivers (Kim, 2009). A total of 18 haplotypes, representing five genera of the family, were

246 identified (Fig. 4). Two haplotypes in the genus Cobitis identified in the Seomjin River were

247 most closely related to C. tetralineata (LC146139) sampled in Japan, with $100 \%$ and $99 \%$

248 sequence identity. Two haplotypes from the Taehwa River showed $98 \%$ and $97 \%$ identity to $C$.

249 hankugensis (LC146140). Two species of Misgurnus are reported from the Korean waters, $M$.

250 mizolepis and M. anguillicaudatus (Kim, 2009). Interestingly, two phylogenetically distinct

251 clades in M. anguillicaudatus were identified in the phylogenetic analysis (Fig. 4). One of them

252 was grouped with the haplotype of M. bipartitus (KF562047) sampled in China, while the other

253 was clustered with the M. mizolepis (AP017654) sampled in Korea. Misgurnus bipartitus is

254 currently reported to be endemic to China, and sequence data of Korean freshwater fishes in

255 GenBank data should be reexamined. 
257 (TH4; KM186182) showed 100\% identity with haplotypes of Paramisgurnus dabryanus sampled

258 in China (Fig. 4). This species is regarded as endemic to China, but $P$. dabryanus is often

259 imported to Korea together with Misgurnus anguillicaudatus due to their phenotypic similarity.

260 Shimizu and Takagi (2010) concluded that there are different populations of $P$. dabryanus

261 (Shimizu and Takagi, 2010), and the two haplotypes of the species identified herein suggest that

262 P. dabryanus has been imported from various locations in China. One haplotype from the

263 Taehwa River (TH1) showed $100 \%$ identity to a sequence of Niwaella multifaciata (EU670806)

264 sampled in Korea, while another from the Hyeongsan River (HS1) showed a lower (96 \%)

265 identity to Niwaella sp. Therefore, further studies should be conducted to confirm the presence of

266 species of this genus in the Hyeongsan River.

267

268 Other families of Teleostei

269 In addition to the three main families of Teleostei identified in this study, 27 additional

270 haplotypes were found in the samples. These haplotypes represented 19 species belonging to14

271 genera and 11 families, namely Amblycipitidae (1), Anguillidae (1), Bagridae (5 haplotypes),

272 Centrarchidae (3), Channidae (1), Clupeidae (2), Mugilidae (4), Odontobutidae (3),

273 Pleuronectidae (1), Siluridae (3), and Sinipercidae (3). All the haplotypes of the family Bagridae

274 were elearly identified and included: Pseudobargrus ussuriensis, P. koreanus, Tachysurrus

275 nitidus, and T. fulvidraco (Fig. 5). Two species of Silurus are currently known in Korean rivers,

276 S. microdorsalis and S. asotus (Park and Kim, 1994). One haplotype from the Taehwa River

277 (TH1) showed $99 \%$ identity to a sequence of Silurus microdorsalis (GenBank Number: 
278 KT350610) sampled in Korea, whereas another haplotype from the Seomjin River (SJ1) showed

279 a lower identity (96 \%) with S. microdorsalis (KT350610) sampled in Korea.

280 One haplotype of the Amblycipitidae from the Seomjin River showed $97 \%$ and $96 \%$

281 identity to Liobagrus styani (KX096605) and L. mediadiposalis (KR075136), sampled in China

282 and Korea, respectively. These results indicate that haplotypes of the family should be

283 supplemented for accurate identification. Three species of Odontobutis are currently known in

284 Korea: O. interrupta, O. platycephala, and O. obscura (Kim et al., 2005). Two of them $(O$.

285 interrupta and O. platycephala) were identified in this study with $100 \%$ identity to the

286 sequences of $O$. interrupta and O. platycephala sampled in Korea (KR364945 and KM030426).

287 Two haplotypes of the genus Coreoperca showed $100 \%$ and $97 \%$ sequence identity to

288 Coreoperca herzi (KR075132) sampled in Korea. Since two species of Coreoperca are reported

289 to be endemic to the Korean Peninsula (Kim et al., 2005), the second haplotype is most likely $C$.

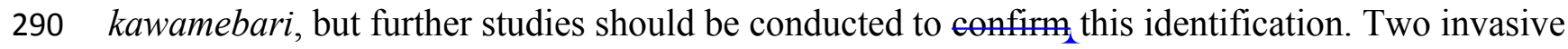

291 species of the family Centrarchidae, the Bluegill (Lepomis macrochirus) and the Largemouth

292 bass (Micropterus salmoides) were also identified in this study. These two species are endemic

293 to North America but were introduced in the Korean Peninsula for aquaculture purposes without

294 considering their impact on local ecosystems.

295

296 Fish biodiversity in the four rivers

297 Fish assemblages in the four rivers included in this study were analyzed. Among the 73

298 confirmed fish species detected in this study, 13 were identified in all four rivers: Anguilla

299 japonica, Hemibarbus labeo, Konosirus punctatus, Micropterus salmoides, Misgurnus mizolepis,

300 Mugil cephalus, Opsariichthys uncirostris, Pseudorasbora parva, Rhinogobius brunneus, 
301 Rhynchocypris lagowskii, Silurus asotus, Tridentiger obscurus, and Zacco platypus (Fig. 6).

302 Regardless of sample stations, species of the Cyprinidae appear to be dominant, with average

303 proportions of $47.02 \pm 6.73 \%$, followed by the Gobiidae $(15.24 \pm 3.07 \%)$ and Cobitidae $(9.95 \pm$

$3044.09 \%$; Fig.7). However, the proportions of species in those families were different between

305 upstream and downstream stations. The proportion of Cyprinidae species was higher (45.27士

$3069.1 \%$ ) upstream (stations 1 and 2$)$ than downstream (33.78 $\pm 18 \%$ at station 4$)$. In contrast, the

307 proportion of Gobiidae was lower (14.53 $\pm 8.28 \%$ ) upstream than downstream (station 4, 19.90

$308 \pm 14 \%)$

309 The highest number of species was recorded in the Seomjin River (52 species), followed by

310

311

312

313

314

315

316

317

318

319

320

321

322

323

the Taehwa (42 species), Hyeongsan (40 species), and Nakdong (26 species) rivers. A total of 17 species were exclusively recorded in the Seomjin River: Acanthogobius hasta, Acheilognathus intermedia, A. majusculus, A. rhombeus, Cobitis tetralineata, Coreoleuciscus splendidus,

Kareius bicoloratus, Microphysogobio yaluensis, Phoxinus oxycephalus, Pseudobagrus

koreanus, Rhodeus suigensis, R. uyekii, Sarcocheilichthys variegatus, Siniperca scherzeri,

Squalidus gracilis, Tanakia somjinensis, and T. signifier. Five species were only recorded in the

Taehwa River: Acanthogobius lactipes, Mugilogobius abei, Pseudogobius masago,

Rhynchocypris semotilus, and Silurus microdorsalis, whereas four species were only identified in the Nakdong River: Plagiognathops microlepis, Pseudobagrus ussuriensis, Rhinogobius giurinus, and Tachysurus nitidus. Finally, only three species (Nipponocypris koreanus, Sarcocheilichthys soldatovi, and Squalidus multimaculatus) were exclusively recorded in the Hyeongsan River (Fig. $6)$.

The highest Shannon index (SI) was identified in the Seomjin River (3.480), followed by the Taehwa (3.067), Hyeongsan (2.954), and Nakdong (2.864) rivers. Among the 16 surveyed 
324 stations, station 1 of the Seomjin River (SJ1) showed the highest species richness (2.197),

325 whereas the lowest richness (1.008) was recorded atthe station 4 of the Nakdong River (ND4).

326 From upstream to downstream, average species richness decreased from 1.951 to 1.415 (Table 4).

327

328 Clustering analysis

329 In order to assess the correlation between the fish assemblage and sample stations, we conducted 330 a heat-map analysis with the 30 most abundant species using Primer software (Clarke and Gorley, 331 2015). The results indicate the species distribution in different sampling stations (Fig. 8). In 332 upstream sites (Stations 1 and 2), the dominant species were A. intermedia, Coreoperca herzi, 333 Misgurnus mizolepis, Nipponocypris temminckii, Rhynchocypris lagowskii, Odontobutis 334 interrupta, O. platycephala, Tanakia signifier, and Zacco platypus. At station 3, the dominant 335 species were Gymnogobius breunigii, Mugil cephalus, Pseudorasbora parva, Rhinogobius 336 giurinus, and R. brunneus. Finally, in the downstream sample (Station 4), Anguilla japonica, 337 Konosirus punctatus, Mugil cephalus, Planiliza haematocheila, Tridentiger obscurus, and T. 338 trigonocephalus were identified as the dominant species, all of which were either euryhaline or 339 anadromous (https://www.fishbase.org).

\section{DISCUSSION}

342 The results indicate that eDNA metabarcoding using the MiFish pipeline is a useful tool for 343 assessing fish biodiversity in Korean freshwater ecosystems, since a total of 125 unique 344 haplotypes, including at least 73 species, were successfully identified by a single-day survey of 34516 sampling stations in four rivers (Fig. 2-5). According to the "Survey and Evaluation of 346 Aquatic Ecosystem Health (SEAEH)," a total of 130 freshwater fish species, were identified from 
347953 sampling sites that covered most of the Korean rivers and lakes (Yoon et al., 2012). The total

348 number of species confirmed by eDNA metabarcoding was equivalent to approximately $56 \%$ of

349 those obtained by the year-long conventional surveys. The efficiency of eDNA metabarcoding

350 might actually be even higher, especially considering the number of haplotypes successfully

351 identified at the genus and/or family level. This result indicates that eDNA metabarcoding with

352 the MiFish pipeline can significantly contribute to the assessment of freshwater fish biodiversity

353 in Korea, especially considering its relatively lower cost of implementation when compared with

354 more conventional morphology-based surveys. Although the methodology in each research

355 group may be slightly different, similar conclusions have been reached in other studies (Bista et

356 al., 2017; Deiner et al., 2016). eDNA metabarcoding analysis is also adequate for surveying

357 aquatic species in protected areas, as it minimizes disturbance of vulnerable communities

358 (Fernandez et al., 2018).

359 Despite its relevance as a methodology for the assessment of biodiversity, there are still a

360 few shortcomings for a more widespread use of eDNA metabarcoding by the MiFish pipeline.

361 First, MiFish sequence data for endemic species of Korea should be supplemented to the

362 GenBank database. According to the Archive of Korean species (https://species.nibr.go.kr), 67

363 species of freshwater fishes are endemic to Korea, and many of their MiFish sequences are still

364 not available in the GenBank database. In addition to the lack of sequence data, freshwater fishes

365 typically have intra-species genetic distances that are generally higher than those of marine

366 species (Seehausen and Wagner, 2014). Second, the MiFish primer amplifies the 12S rRNA gene

367 (163-185 bp) region of mitochondrial DNA, which is smaller and less variable than the COI

368 region, which is typically used in species identification (IVANOVA et al., 2007). In fact, the

369 MiFish region was unable to differentiate several closely related marine fish taxa, such as 
370 those in the genus Sebastes and Takifugu (Sato et al., 2018; Yamamoto et al., 2017). We also

371 found that the average genetic distance of several genera in the family Cyprinidae was low in the

372 MiFish region. For example, the average genetic distance of Carassius species was too low (0.01)

373 and the identification at the species level was not possible (Fig. 2).

374 Further studies using eDNA metabarcoding might also be relevant to obtain more than

375 biodiversity data, such as the quantitative analysis of fish species. It is difficult to estimate the 376 spatial abundance of eDNA in lotic environments. In fact, many factors should be considered for

377 the quantitative analysis of eDNAs in rivers, including water dynamics (Deiner and Altermatt,

378 2014; Jerde et al., 2016; Wilcox et al., 2016) or different decaying times due to different physical,

379 chemical, or biological factors (Shapiro, 2008). It is generally known that shorter fragments of

380 DNA are degraded slower than larger ones, increasing their probability of detection in natural

381 environments (Deagle et al., 2006). Therefore, it is still too early to adopt eDNA metabarcoding

382 for the quantitative analysis of fish species under natural conditions. For the quantitative study,

383 standardized collection methods and pretreatment procedures for NGS sequencing analysis

384 should also be established. One of the strongest points in the biodiversity survey by eDNA

385 metabarcoding is the quantity of information it can generate compared with more conventional

386 surveys since large datasets are useful for statistical analyses. However, large amounts of data

387 have been produced using different water collection methods, eDNA preparation, sequencing,

388 and bioinformatic analysis platforms by different research groups in different countries.

389 Therefore, the interconversion of data is currently not possible. The establishment of an

390 international standard regarding the overall methodology of eDNA metabarcoding would help

391 researchers to produce more comparable data. 
According to the results obtained in this study, the highest species richness was found in the

393

394

395

396

397

398

399

400

401

402

403

404

405

406

407

408

409

410

411

412

413

Seomjin River (3.48) compared with those of the other three rivers: the Taehwa River (3.06),

Hyeongsan River (2.95), and Nakdong River (2.86). The lower values of species richness

detected in the Nakdong, Hyeongsan, and Taehwa rivers are presumably related to the higher

anthropogenic alteration of the natural conditions in those rivers. Like most other Korean rivers,

these three rivers run through highly populated metropolitan cities, in which rivers are exposed

to various human impacts that directly or indirectly promote changes in the diversity and

distribution of freshwater fishes (Finkenbine et al., 2000). In particular, the lowest species

richness (2.86) and number of endemic species (only one, Odontobutis interrupta) were

identified in the Nakdong River, where the highest number of constructions and population exist

among the sampled rivers. Lee et al. (2015) reported only two endemic species (Coreoperca

herzi and Odontobutis platycephala) in the Nakdong River using a conventional catch survey.

Moreover, eight endemic species(Coreoleuciscus splendidus, Iksookimia longicorpa,

Microphysogobio koreensis, M. yaluensis, Odontobutis interrupta, O. platycephala,

Pseudobagrus koreanus, and Squalidus gracilis) were identified in this study in the Seomjin

River, a number that is similar to those obtained in previous studies (Jang et al., 2003; Lee et al.,

2015). Several constructions along urbanized watersheds, including dams and weirs, have caused

the simplification and reduction of habitats, decreasing the biodiversity in the river (Nilsson et al.,

2005; Riley et al., 2005). In contrast, there is no metropolitan city along the Seomjin River,

which is, therefore, less exposed to anthropogenic impacts. A long-term survey should be

conducted to establish a clear correlation between anthropogenic factors and fish assemblages in

the Korean rivers.

Peer) reviewing PDF | (2019:11:43068:3:1:CHECK 4 Jun 2020) 
The eDNA metabarcoding analysis also indicates that some exotic fish species are widely

415 distributed in Korean rivers. We were able to identify at least five exotic fish species: Carassius

417 salmoides (Table S3). These exotic species may affect native fishes in terms of shelter and 418 spawning sites. They can also disturb the food chain, preying on native fish In $_{2}$ addition, these

419 species have a high reproductive capacity, which makes them important potentially invasive 420 species (Keller \& Lake, 2007; Koster et al., 2002; Nico \& Fuller, 2010). Surprisingly, our results

421 also revealed that the largemouth bass, M. salmoides, and the bluegill, L. macrochirus, are likely 422 present in all the sampled rivers. These two species, which are native to North America, were 423 artificially introduced in the 1970s in Korea as freshwater fish stock, without any further 424 consideration of the effects on the freshwater ecosystems of the country. They are now widely 425 distributed throughout the Korean Peninsula, competing with the native species. A long-term 426 survey of these rivers should be conducted to properly assess the potential impacts of these 427 introduced species (Jang et al., 2002; Yoon et al., 2012). Freshwater ecosystems are much more 428 vulnerable to invasive species, causing biodiversity loss and global climate change (Clavero and 429 García-Berthou, 2005), and eDNA metabarcoding analyses would be useful for monitoring the 430 distribution patterns of invasive species in Korean rivers.

\section{Acknowledgments}

433 The authors are thankful to the Ministry of Oceans and Fisheries of the Republic of Korea. The 434 authors also thank the reviewers for their valuable comments and suggestions for the manuscript. 


\section{Funding:}

438 This research was a part of the project titled "Long-term change of structure and function in 439 marine ecosystems of Korea", funded by the Ministry of Oceans and Fisheries, Korea.

\section{Role of funding}

442 The funding sources had no role in the research design, sample collection, data analysis, 443 manuscript writing, or the decision to submit the article for publication.

444

\section{Competing Interests}

446 The authors declare that they have no competing interests.

447

448

Author Contributions

449

- Md. Jobaidul Alam collected the samples, performed the experiments, analyzed the data, prepared

450 figures and/or tables, and wrote the manuscript.

451 - Nack-Keun Kim collected the samples and analyzed the data

452 - Sapto Andriyono performed the experiments, analyzed the data, prepared figures, and/or tables

453

- Hee-Kyu Choi analyzed the data, prepared figures, and/or tables

- Ji-Hyun Lee analyzed the data, prepared figures, and/or tables

- Hyun-Woo Kim conceived and designed the experiments, analyzed the data, contributed reagents/materials/analysis tools, authored or reviewed drafts of the manuscript, approved the final draft, and wrote the manuscript.

458

459

\section{REFERENCES}

Arai, R., 1988. Acheilognathus melanogaster, a senior synonym of A moriokae, with a revision of the genera of the subfamily Acheilogathinae (Cypriniformes, Cyprinidae). Bul Nat Sci Mus Tokyo Ser A 14, 199-213.

Ardura, A., Zaiko, A., Martinez, J.L., Samulioviene, A., Semenova, A., Garcia-Vazquez, E., 2015. eDNA 
468 Bista, I., Carvalho, G.R., Walsh, K., Seymour, M., Hajibabaei, M., Lallias, D., Christmas, M., Creer, S.,

469 2017. Annual time-series analysis of aqueous eDNA reveals ecologically relevant dynamics of lake

470 ecosystem biodiversity. Nature communications 8, 14087.

471 Cai, W., Ma, Z., Yang, C., Wang, L., Wang, W., Zhao, G., Geng, Y., Douglas, W.Y., 2017. Using eDNA 472 to detect the distribution and density of invasive crayfish in the Honghe-Hani rice terrace World Heritage 473 site. PloS one 12, e0177724.

474 Clarke, K., Gorley, R., 2015. Getting started with PRIMER v7. PRIMER-E: Plymouth, Plymouth Marine 475 Laboratory.

476 Clavero, M., García-Berthou, E., 2005. Invasive species are a leading cause of animal extinctions. Trends 477 in Ecology \& Evolution 20, 110.

478 Clusa, L., Miralles, L., Basanta, A., Escot, C., García-Vázquez, E., 2017. eDNA for detection of five

479 highly invasive molluscs. A case study in urban rivers from the Iberian Peninsula. PloS one 12, e0188126.

480 Deagle, B.E., Eveson, J.P., Jarman, S.N., 2006. Quantification of damage in DNA recovered from highly degraded samples-a case study on DNA in faeces. Frontiers in zoology $3,11$.

482 Deiner, K., Altermatt, F., 2014. Transport distance of invertebrate environmental DNA in a natural river.

483 PloS one 9, e88786.

484 Deiner, K., Fronhofer, E.A., Mächler, E., Walser, J.-C., Altermatt, F., 2016. Environmental DNA reveals

485 that rivers are conveyer belts of biodiversity information. Nature communications 7, 12544.

486

487

488

489

490

491

492

493

494

495

496

497

498

499

500

501

502

503
Dejean, T., Valentini, A., Miquel, C., Taberlet, P., Bellemain, E., Miaud, C., 2012. Improved detection of an alien invasive species through environmental DNA barcoding: the example of the American bullfrog Lithobates catesbeianus. Journal of applied ecology 49, 953-959.

Dudgeon, D., 2010. Prospects for sustaining freshwater biodiversity in the 21 st century: linking ecosystem structure and function. Current Opinion in Environmental Sustainability 2, 422-430.

Fernandez, S., Sandin, M.M., Beaulieu, P.G., Clusa, L., Martinez, J.L., Ardura, A., García-Vázquez, E., 2018. Environmental DNA for freshwater fish monitoring: insights for conservation within a protected area. PeerJ 6, e4486.

Finkenbine, J.K., Atwater, J., Mavinic, D., 2000. STREAM HEALTH AFTER URBANIZATION 1. JAWRA Journal of the American Water Resources Association 36, 1149-1160.

Foote, A.D., Thomsen, P.F., Sveegaard, S., Wahlberg, M., Kielgast, J., Kyhn, L.A., Salling, A.B., Galatius, A., Orlando, L., Gilbert, M.T.P., 2012. Investigating the potential use of environmental DNA (eDNA) for genetic monitoring of marine mammals. PloS one 7, e41781.

Gray, J.S., 2000. The measurement of marine species diversity, with an application to the benthic fauna of the Norwegian continental shelf. Journal of experimental marine biology and ecology 250, 23-49.

Gustavson, M., Collins, P., Finarelli, J., Egan, D., Conchúir, R., Wightman, G., King, J., Gauthier, D., Whelan, K., Carlsson, J., 2015. An eDNA assay for Irish Petromyzon marinus and Salmo trutta and field validation in running water. Journal of Fish Biology 87, 1254-1262. 
504 IVANOVA, N.V., ZEMLAK, T.S., HANNER, R.H., HEBERT, P.D.N., 2007. Universal primer cocktails 505 for fish DNA barcoding. Molecular Ecology Notes 7, 544-548.

506 Jang, M.-H., Lucas, M.C., Joo, G.-J., 2003. The fish fauna of mountain streams in South Korean national 507 parks and its significance to conservation of regional freshwater fish biodiversity. Biological

508 Conservation 114, 115-126.

509 Jang, M.H., Kim, J.G., Park, S.B., Jeong, K.S., Cho, G.I., Joo, G.J., 2002. The current status of the

510 distribution of introduced fish in large river systems of South Korea. International Review of

511 Hydrobiology 87, 319-328.

512 Jerde, C.L., Olds, B.P., Shogren, A.J., Andruszkiewicz, E.A., Mahon, A.R., Bolster, D., Tank, J.L., 2016.

513 Influence of stream bottom substrate on retention and transport of vertebrate environmental DNA.

514 Environmental science \& technology 50, 8770-8779.

515 Kelly, R.P., Closek, C.J., O'Donnell, J.L., Kralj, J.E., Shelton, A.O., Samhouri, J.F., 2017. Genetic and 516 manual survey methods yield different and complementary views of an ecosystem. Frontiers in Marine

517 Science 3, 283.

518 Kelly, R.P., Port, J.A., Yamahara, K.M., Martone, R.G., Lowell, N., Thomsen, P.F., Mach, M.E., Bennett, 519 M., Prahler, E., Caldwell, M.R., 2014. Harnessing DNA to improve environmental management. Science $520344,1455-1456$.

521 Kim, I.-S., 2009. A Review of the Spined Loaches, Family Cobitidae (Cypriniformes) in Korea Korean 522 Journal of Ichthyology 21, 7-28.

523 Kim, I.-S., Park, J.-Y., 2002. Freshwater fishes of Korea. Kyo hak sa.

524 Kim, I., Choi, Y., Lee, C., Lee, Y., Kim, B., Kim, J., 2005. Illustrated book of Korean fishes. Kyo-Hak

525 Publishing, 417-418.

526 Kitamura, J.-i., 2007. Reproductive ecology and host utilization of four sympatric bitterling

527 (Acheilognathinae, Cyprinidae) in a lowland reach of the Harai River in Mie, Japan. Environmental

528 Biology of Fishes 78, 37-55.

529 Kitamura, J., Nagata, N., Nakajima, J., Sota, T., 2012. Divergence of ovipositor length and egg shape in a 530 brood parasitic bitterling fish through the use of different mussel hosts. Journal of evolutionary biology

$53125,566-573$.

532 Klymus, K.E., Marshall, N.T., Stepien, C.A., 2017. Environmental DNA (eDNA) metabarcoding assays

533 to detect invasive invertebrate species in the Great Lakes. PloS one 12, e0177643.

534 Ko, M., Kim, K., Park, J., 2011. Red Data Book of endangered fishes in Korea. National Institute of

535 Biological Resources, Incheon.(in Korean).

536 Kumar, S., Stecher, G., Tamura, K., 2016. MEGA7: molecular evolutionary genetics analysis version 7.0

537 for bigger datasets. Molecular biology and evolution 33, 1870-1874.

538 Lee, J.W., Yoon, J.D., Kim, J.H., Park, S.H., Baek, S.H., Yu, J.J., Jang, M.H., Min, J.I., 2015.

539 Length-weight relationships for 18 freshwater fish species from the Nakdong River in South Korea.

540 Journal of Applied Ichthyology 31, 576-577. 
541 Lee, W.-O., Zhang, M.-M., Oh, C.-W., Baek, J.-M., Song, K.-J., 2012. Age and Growth of Barbel Steed

542 Hemibarbus labeo in Goe-san Lake in Korea. Fisheries and aquatic sciences 15, 353-359.

543 Magurran, A.E., 1988. Ecological diversity and its measurement. Princeton university press.

544 Miya, M., Sato, Y., Fukunaga, T., Sado, T., Poulsen, J.Y., Sato, K., Minamoto, T., Yamamoto, S.,

545 Yamanaka, H., Araki, H., 2015a. MiFish, a set of universal PCR primers for metabarcoding

546 environmental DNA from fishes: detection of more than 230 subtropical marine species. Royal Society

547 open science 2, 150088.

548 Miya, M., Sato, Y., Fukunaga, T., Sado, T., Poulsen, J.Y., Sato, K., Minamoto, T., Yamamoto, S.,

549 Yamanaka, H., Araki, H., Kondoh, M., Iwasaki, W., 2015b. MiFish, a set of universal PCR primers for

550 metabarcoding environmental DNA from fishes: detection of more than 230 subtropical marine species.

551 Royal Society Open Science 2.

552 Nilsson, C., Reidy, C.A., Dynesius, M., Revenga, C., 2005. Fragmentation and flow regulation of the

553 world's large river systems. Science 308, 405-408.

554 Park, S.-W., Kim, Y.-G., 1994. Studies on disease of catfish, Silurus asotus, in Korea. III. Edwardsiella

555 ictaluri infection. Journal of fish pathology 7, 105-112.

556 Pilliod, D.S., Goldberg, C.S., Laramie, M.B., Waits, L.P., 2013. Application of environmental DNA for

557 inventory and monitoring of aquatic species. US Department of the Interior, US Geological Survey.

558 Pont, D., Rocle, M., Valentini, A., Civade, R., Jean, P., Maire, A., Roset, N., Schabuss, M., Zornig, H.,

559 Dejean, T., 2018. Environmental DNA reveals quantitative patterns of fish biodiversity in large rivers

560 despite its downstream transportation. Scientific reports 8, 10361.

561 Riaz, T., Shehzad, W., Viari, A., Pompanon, F., Taberlet, P., Coissac, E., 2011. ecoPrimers: inference of

562 new DNA barcode markers from whole genome sequence analysis. Nucleic Acids Research 39, e145-

$563 \mathrm{e} 145$.

564 Riley, S.P., Busteed, G.T., Kats, L.B., Vandergon, T.L., Lee, L.F., Dagit, R.G., Kerby, J.L., Fisher, R.N.,

565 Sauvajot, R.M., 2005. Effects of urbanization on the distribution and abundance of amphibians and

566 invasive species in southern California streams. Conservation Biology 19, 1894-1907.

567 Sato, Y., Miya, M., Fukunaga, T., Sado, T., Iwasaki, W., 2018. MitoFish and MiFish Pipeline: A

568 Mitochondrial Genome Database of Fish with an Analysis Pipeline for Environmental DNA

569 Metabarcoding. Molecular Biology and Evolution 35, 1553-1555.

570 Seehausen, O., Wagner, C.E., 2014. Speciation in Freshwater Fishes. Annual Review of Ecology,

571 Evolution, and Systematics 45, 621-651.

572 Shapiro, B., 2008. Engineered polymerases amplify the potential of ancient DNA. Trends in

573 biotechnology 26, 285-287.

574 Shaw, J.L.A., Clarke, L.J., Wedderburn, S.D., Barnes, T.C., Weyrich, L.S., Cooper, A., 2016.

575 Comparison of environmental DNA metabarcoding and conventional fish survey methods in a river

576 system. Biological Conservation 197, 131-138. 
577 Shimizu, T., Takagi, M., 2010. Two genetic clades in populations of Paramisgurnus dabryanus, an exotic 578 invader in ehime prefecture. Jpn J Ichthyol 57, 125-134.

579 Stoeckle, M.Y., Soboleva, L., Charlop-Powers, Z., 2017. Aquatic environmental DNA detects seasonal 580 fish abundance and habitat preference in an urban estuary. PLOS ONE 12, e0175186.

581 Takahara, T., Minamoto, T., Doi, H., 2013. Using environmental DNA to estimate the distribution of an invasive fish species in ponds. PloS one 8, e56584.

583 Ushio, M., Murakami, H., Masuda, R., Sado, T., Miya, M., Sakurai, S., Yamanaka, H., Minamoto, T., 584 Kondoh, M., 2017. Quantitative monitoring of multispecies fish environmental DNA using high585 throughput sequencing. bioRxiv.

586 Wilcox, T.M., McKelvey, K.S., Young, M.K., Sepulveda, A.J., Shepard, B.B., Jane, S.F., Whiteley, A.R., 587 Lowe, W.H., Schwartz, M.K., 2016. Understanding environmental DNA detection probabilities: A case

588 study using a stream-dwelling char Salvelinus fontinalis. Biological Conservation 194, 209-216.

589 Williams, K.E., Huyvaert, K.P., Vercauteren, K.C., Davis, A.J., Piaggio, A.J., 2018. Detection and 590 persistence of environmental DNA from an invasive, terrestrial mammal. Ecology and evolution 8, 688591695.

592 Yamamoto, S., Masuda, R., Sato, Y., Sado, T., Araki, H., Kondoh, M., Minamoto, T., Miya, M., 2017.

593 Environmental DNA metabarcoding reveals local fish communities in a species-rich coastal sea.

594 Scientific reports 7, 40368.

595 Yamamoto, S., Minami, K., Fukaya, K., Takahashi, K., Sawada, H., Murakami, H., Tsuji, S., Hashizume, 596 H., Kubonaga, S., Horiuchi, T., 2016. Environmental DNA as a 'snapshot'of fish distribution: A case 597 study of Japanese jack mackerel in Maizuru Bay, Sea of Japan. PLoS One 11, e0149786.

598 Yamanaka, H., Minamoto, T., 2016. The use of environmental DNA of fishes as an efficient method of 599 determining habitat connectivity. Ecological indicators 62, 147-153.

600 Yoon, J.-D., Jang, M.-H., Kim, H.-W., Joo, G.-J., 2012. Fish Biodiversity Monitoring in Rivers of South

601 Korea, The Biodiversity Observation Network in the Asia-Pacific Region. Springer, 175-191.

602 Zhang, Y., 2015. An Introduction to Python and computer programming, An Introduction to Python and 603 Computer Programming. Springer, 1-11. 
Figure 1

Water sample collection sites of four Korean rivers

Figure 1 Water sample collection sites for environmental DNA metabarcoding study from four Korean rivers 

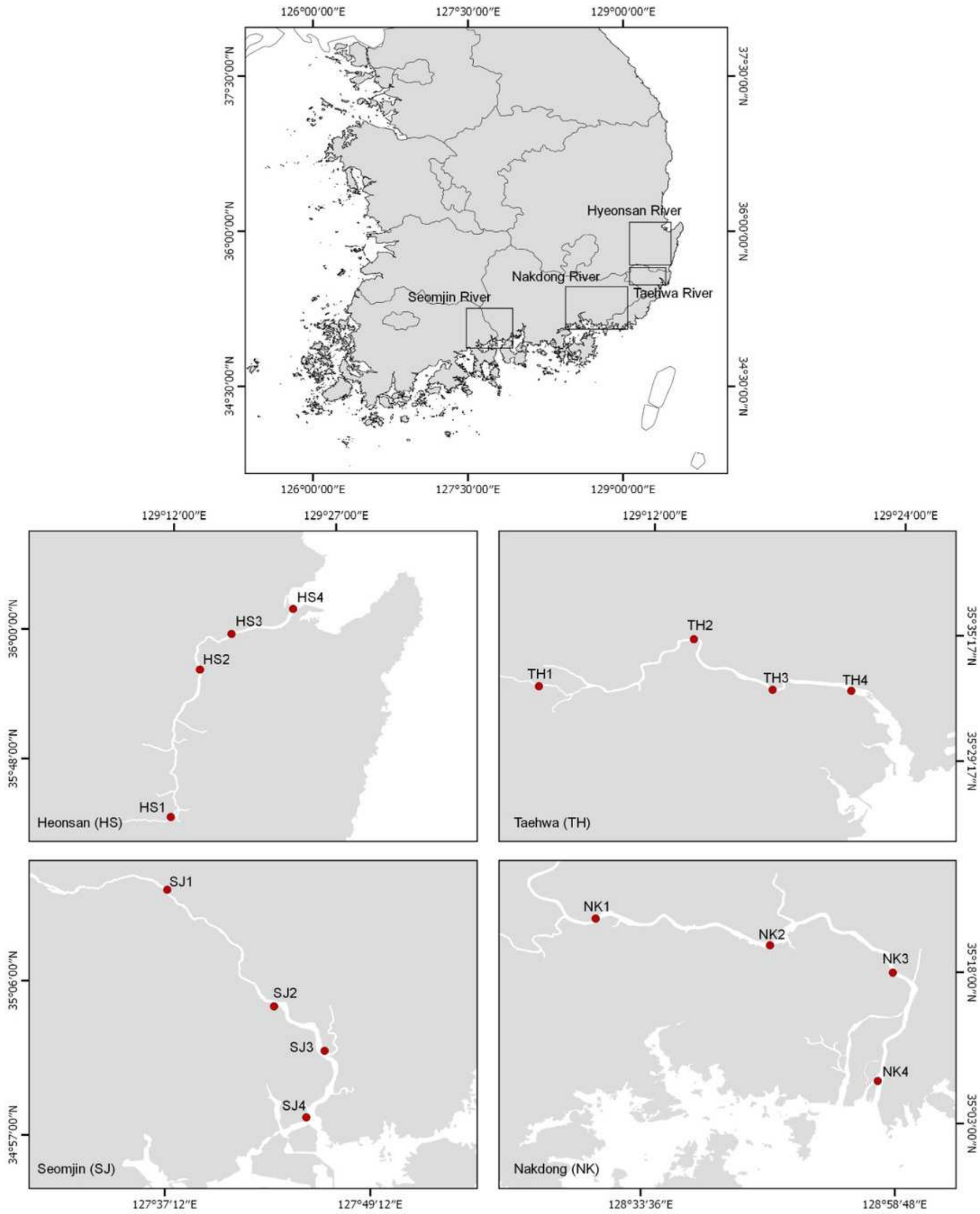


\section{Figure 2}

Phylogenetic tree of the fish species the family Cyprinidae

Figure 2 Phylogenetic tree analysis of fish-species the family Cyprinidae tetected from four Korean rivers. Phylogenetic tree was constructed by Maximum likelihood (ML) algorithm (MEGA 7.0) under the 1000 replication bootstrap.
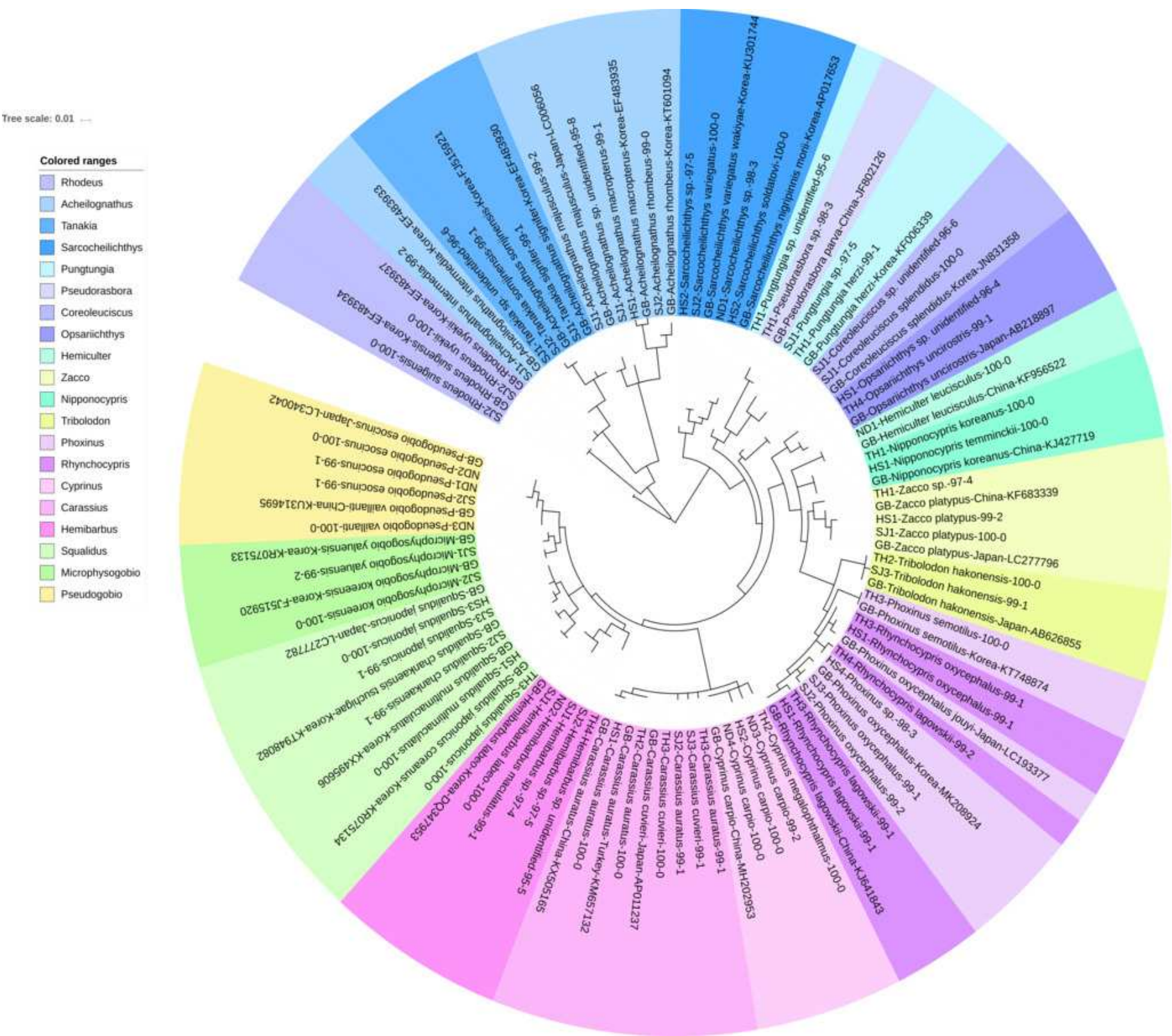


\section{Figure 3}

Phylogenetic tree of the fish species under the family Gobiidae

Figure 3 Phylogenetic tree analysis-of fish species the family Gobiidae. Phylogenetic tree was constructed by Maximum likelihood (ML) algorithm (MEGA 7.0) under the 1000 replication bootstrap.

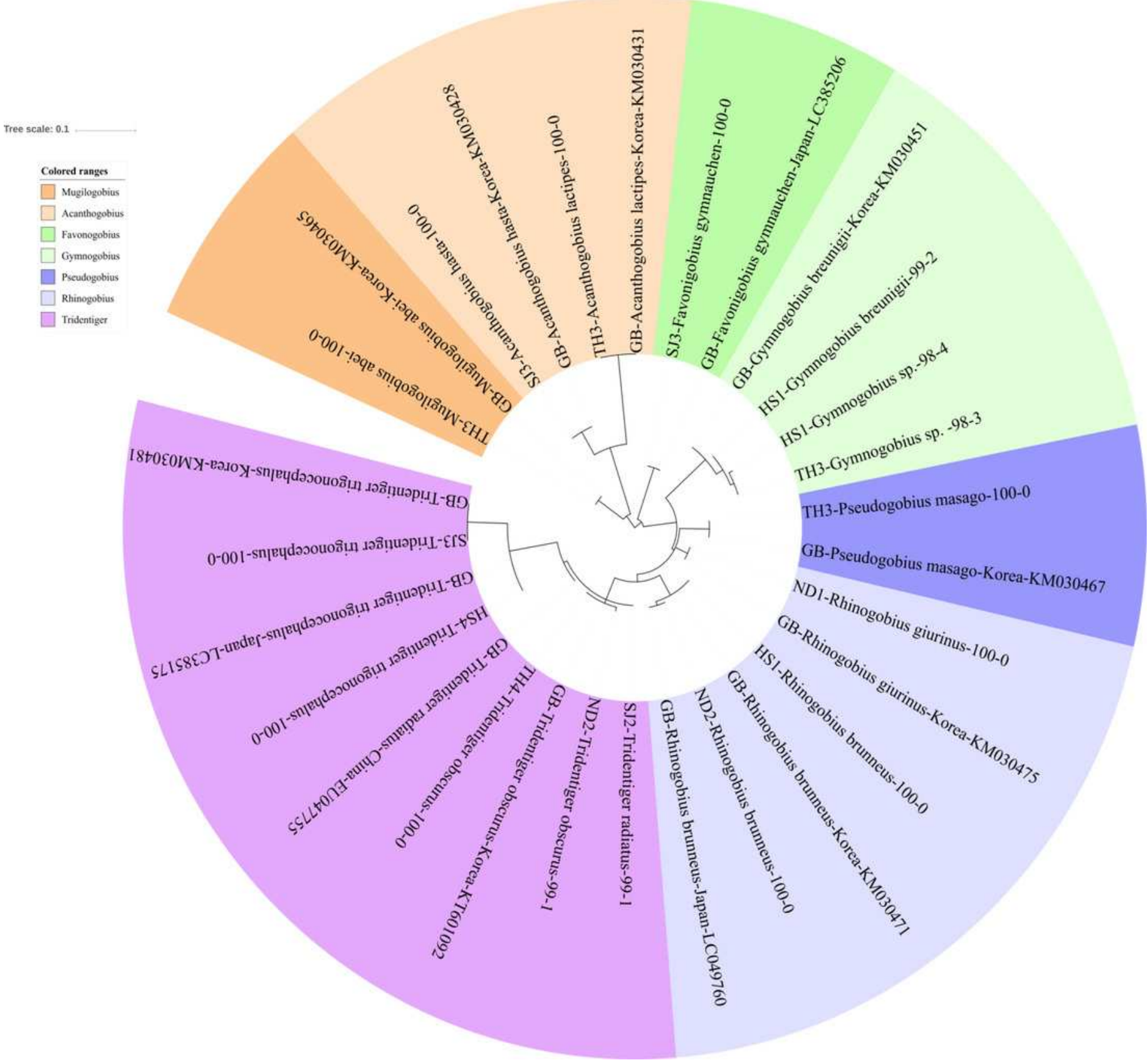




\section{Figure 4}

Phylogenetic tree of the fish species under the family Cobitidae

Figure 4 Phylogenetic tree analysis of fish species under the family Cobitidae. Phylogenetic tree was constructed by Maximum likelihood (ML) algorithm (MEGA 7.0) under the 1000 replication bootstrap.

Tree scale: 0.01

$\frac{\text { Colored ranges }}{\square}$ Koreocobitis
$\square$ Paramisgurnus
$\square$ Paramisgurnus
$\square$ Cobitis
$\square$ Misgurnus
$\square$ Misgurnus
$\square$ Iksookimia
$\square$ Niwaella
$\square$ Kichulchoia

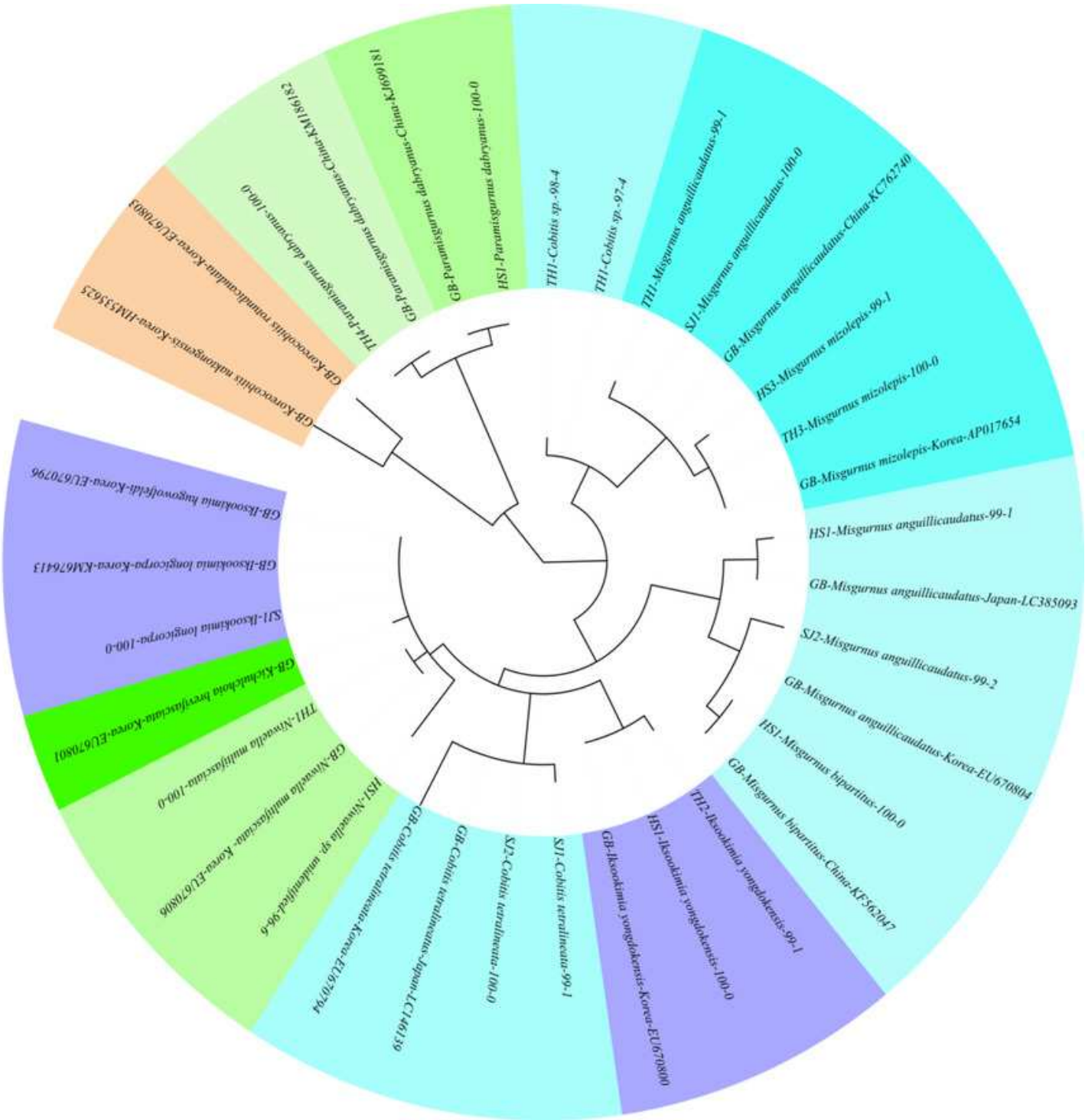




\section{Figure 5}

Phylogenetic tree of the fish species under the other families

Figure 5 Phylogenetic tree analysis of fish species under the other families of Teleostei.

Phylogenetic tree was constructed by Maximum likelihood (ML) algorithm (MEGA 7.0) under the 1000 replication bootstrap.

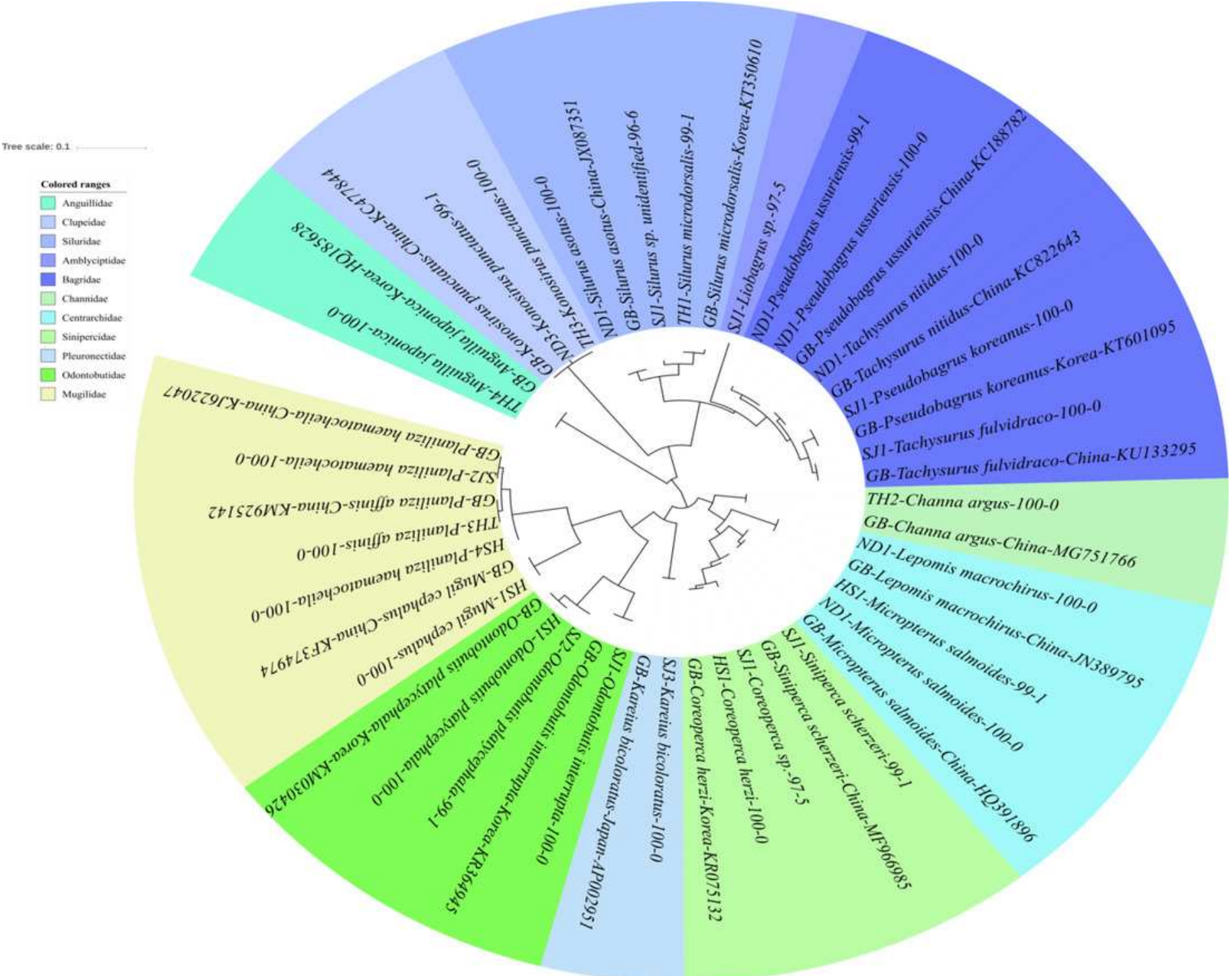




\section{Figure 6}

Venn diagram of fish species identified in the four Korean rivers.

Figure 6 Venn diagram of identified species of fishes in the four Korean rivers. Venn diagram was constructed by an online program ( http://bioinformatics.psb.ugent.be/webtools/Venn/).

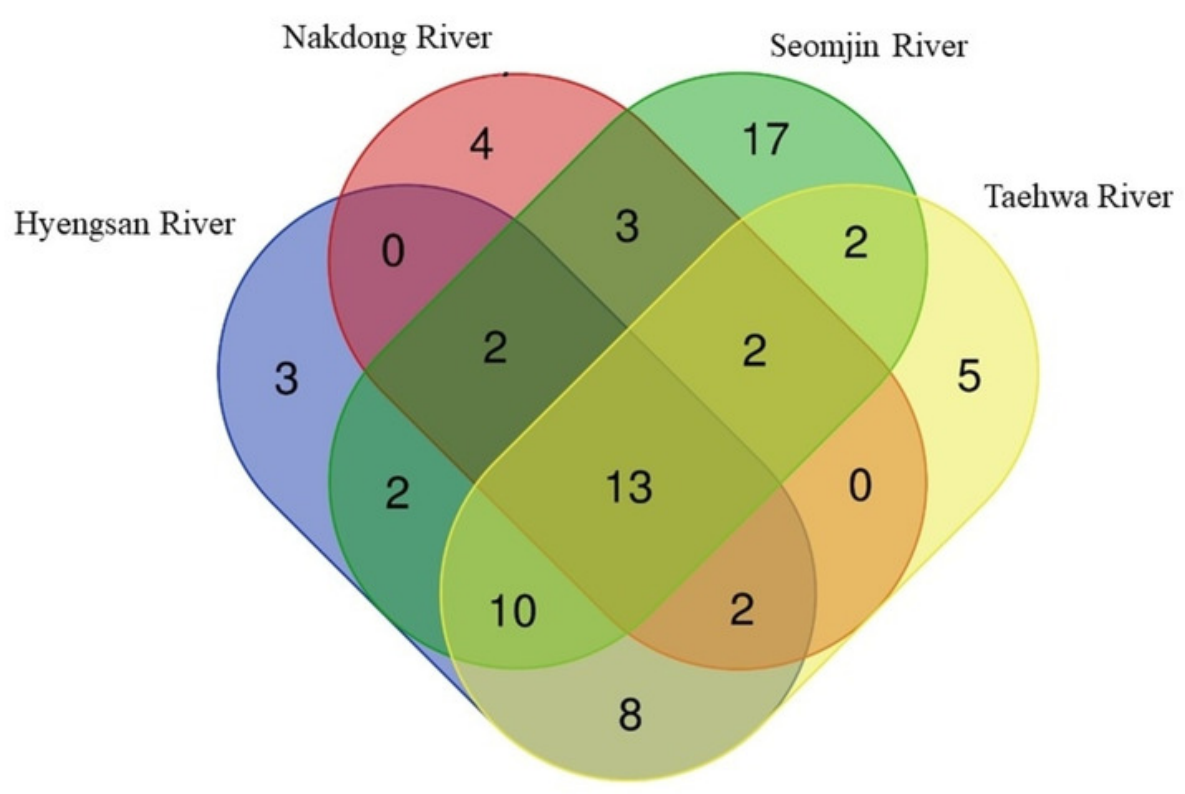




\section{Figure 7}

Proportion of families detected from the four Korean rivers

Figure 7 Proportion of families detected from the four Korean rivers by environmental DNA metabarcoding.

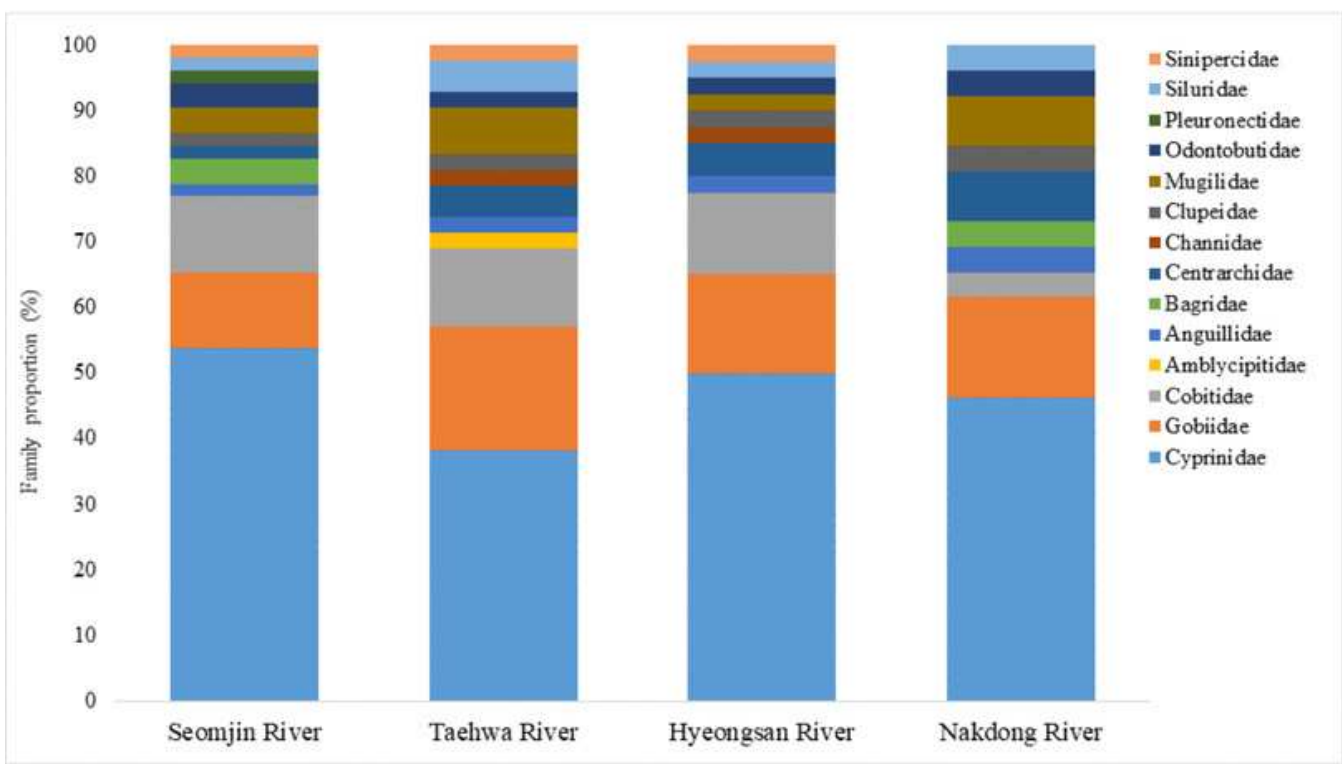


Figure 8

Heat map analysis of top 30 fish species identified in 16 sampling stations of the four Korean rivers.

Figure 8 Heat map analysis of 30 fish species identified in 16 sampling stations of the four Korean rivers. Heat map analysis was constructed by Primer v7 program.

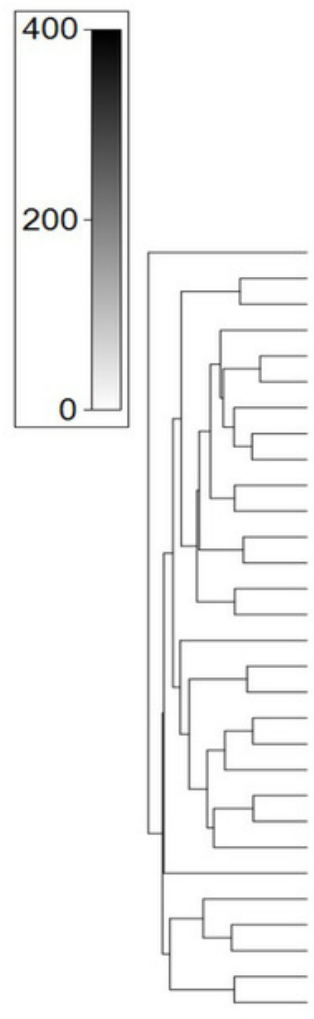

Pseudogobio vaillanti Rhinogobius giurinus Hemibarbus labeo Opsariichthys uncirostris Lepomis macrochirus Micropterus salmoides Tridentiger obscurus Carassius auratus Pseudorasbora parva Hemibarbus maculatus Rhinogobius brunneus Planiliza haematocheila Anguilla japonica Mugil cephalus Tribolodon hakonensis Squalidus japonicus Zacco platypus Odontobutis interrupta Nipponocypris temminckii Odontobutis platycephala Rhynchocypris lagowskii Paramisgurnus dabryanus Misgurnus mizolepis Coreoperca herzi Gymnogobius breunigii Misgurnus bipartitus

Konosirus punctatus Tridentiger trigonocephalus Acheilognathus intermedia
Tanakia signifer

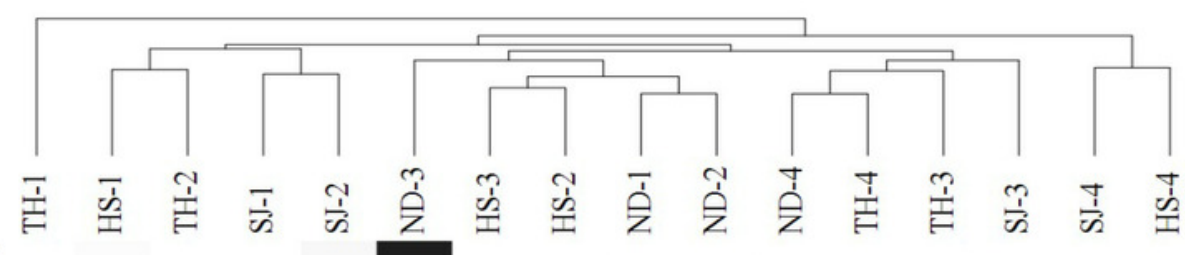




\section{Table 1 (on next page)}

Table 1 Environmental DNA sample collection sites with physico-chemical parameters of the four Korean rivers 
1 Table 1 Environmental DNA sample collection sites with physico-chemical parameters of the four

2 Korean rivers

\begin{tabular}{|c|c|c|c|c|c|}
\hline River & Date & Station & GPS location & $\begin{array}{c}\text { Temp. } \\
\text { (0c) }\end{array}$ & $\begin{array}{l}\text { Salinity } \\
\text { (PSU) }\end{array}$ \\
\hline \multirow[t]{4}{*}{ Hyeongsan } & 2018.06.11 & HS1 & 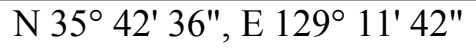 & 18.6 & 1.00 \\
\hline & & HS2 & N 35० 56' 14", E $129^{\circ} 14^{\prime} 24^{\prime \prime}$ & 19.5 & 2.02 \\
\hline & & HS3 & N $35^{\circ} 59^{\prime} 32^{\prime \prime}$, E $129^{\circ} 17^{\prime} 19^{\prime \prime}$ & 20.0 & 3.20 \\
\hline & & HS4 & N 36o 01' 51", E 129 23' 01" & 24.0 & 20.20 \\
\hline \multirow[t]{4}{*}{ Taehwa } & 2018.06 .11 & TH1 & 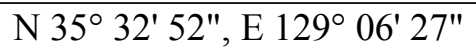 & 19.4 & 1.02 \\
\hline & & TH2 & 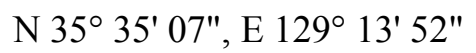 & 19.8 & 2.04 \\
\hline & & TH3 & N 35 $32^{\prime} 42^{\prime \prime}$, E $129^{\circ} 17^{\prime} 38^{\prime \prime}$ & 22.7 & 14.02 \\
\hline & & TH4 & N 35०32' 39", E $129^{\circ} 21^{\prime} 24^{\prime \prime}$ & 19.2 & 17.80 \\
\hline \multirow[t]{4}{*}{ Seomjin } & 2018.06.12 & SJ1 & N 35० 11' 18", E $127^{\circ} 37^{\prime} 21^{\prime \prime}$ & 24.2 & 0.15 \\
\hline & & SJ2 & N 35० 04' 30", E $127^{\circ} 43^{\prime} 35^{\prime \prime}$ & 23.4 & 2.01 \\
\hline & & SJ3 & N 35० 01' 54", E $127^{\circ} 46^{\prime} 32^{\prime \prime}$ & 23.0 & 12.9 \\
\hline & & SJ4 & N 34 58' 01", E $127^{\circ} 45^{\prime} 28^{\prime \prime}$ & 23.25 & 16.8 \\
\hline \multirow[t]{4}{*}{ Nakdong } & 2018.06 .12 & ND1 & 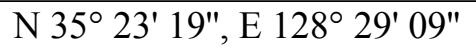 & 24.0 & 1.92 \\
\hline & & ND2 & N $35^{\circ} 20^{\prime} 40^{\prime \prime}$, E $128^{\circ} 46^{\prime} 26^{\prime \prime}$ & 24.1 & 2.40 \\
\hline & & ND3 & N $35^{\circ} 17^{\prime} 57^{\prime \prime}$, E $128^{\circ} 58^{\prime} 37^{\prime \prime}$ & 23.2 & 2.78 \\
\hline & & ND4 & N $35^{\circ} 07^{\prime} 13^{\prime \prime}$, E $128^{\circ} 57^{\prime} 07^{\prime \prime}$ & 22.5 & 4.50 \\
\hline
\end{tabular}




\section{Table 2 (on next page)}

Table 2 Taxonomic assignment summary of of the MiSeq reads from four Korean rivers 
1 Table 2. Summary of taxonomic assignment of the MiSeq reads from four Korean rivers

\begin{tabular}{|l|c|c|c|c|c|}
\hline & $\begin{array}{c}\text { Seomjin } \\
\text { River }\end{array}$ & $\begin{array}{c}\text { Taehwa } \\
\text { River }\end{array}$ & $\begin{array}{c}\text { Hyeongsan } \\
\text { River }\end{array}$ & $\begin{array}{c}\text { Nakdong } \\
\text { River }\end{array}$ & Total \\
\hline Raw reads & 561,473 & 609,755 & 601,165 & 543,212 & $2,315,605$ \\
\hline Processed Merged reads & 553,175 & 600,744 & 592,281 & 534,650 & $2,280,850$ \\
\hline Total Haplotypes & 76 & 67 & 53 & 42 & $238(125)^{*}$ \\
\hline $\begin{array}{l}\text { Haplotypes with species } \\
\text { name }\end{array}$ & 61 & 49 & 48 & 31 & $189(105)^{*}$ \\
\hline Total species & 52 & 42 & 40 & 26 & $160(73)^{*}$ \\
\hline
\end{tabular}

2

$3 *$ Final number, after removal of duplicated one in brackets

4

5 


\section{Table 3(on next page)}

Table 3 List of haplotypes of fishes identified by eDNA metabarcoding study in four Korean rivers 


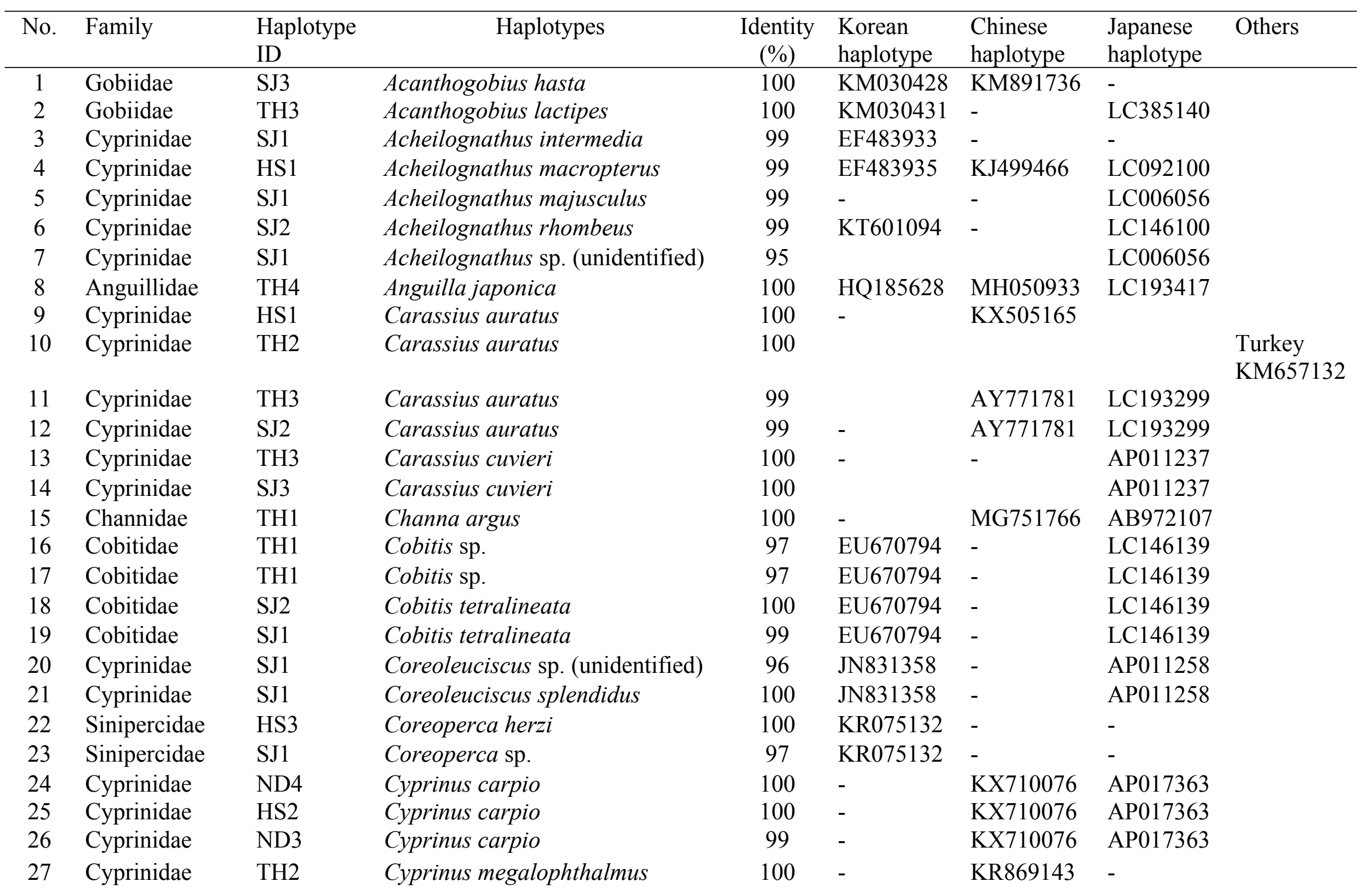




\begin{tabular}{|c|c|c|c|c|c|c|c|c|}
\hline 28 & Gobiidae & $\mathrm{SJ} 3$ & Favonigobius gymnauchen & 100 & - & - & LC385206 & \\
\hline 29 & Gobiidae & HS1 & Gymnogobius breunigii & 99 & KM030451 & - & - & \\
\hline 30 & Gobiidae & HS1 & Gymnogobius sp. & 98 & KM030451 & - & - & \\
\hline 31 & Gobiidae & TH3 & Gymnogobius sp. & 98 & KM030451 & - & - & \\
\hline 32 & Cyprinidae & SJ1 & Hemibarbus labeo & 100 & DQ347953 & KP064328 & LC049898 & \\
\hline 33 & Cyprinidae & ND2 & Hemibarbus maculatus & 99 & - & NC018534 & & \\
\hline 34 & Cyprinidae & SJ1 & Hemibarbus sp. & 97 & DQ347953 & KP064328 & LC049898 & \\
\hline 35 & Cyprinidae & $\mathrm{SJ} 2$ & Hemibarbus sp. & 97 & DQ347953 & KP064328 & LC049898 & \\
\hline 36 & Cyprinidae & TH4 & Hemibarbus sp. (unidentified) & 95 & DQ347953 & KP064328 & LC049898 & \\
\hline 37 & Cyprinidae & ND1 & Hemiculter leucisculus & 100 & - & - & LC340359 & \\
\hline 38 & Cobitidae & SJ1 & Iksookimia longicorpa & 100 & KM676413 & - & LC146135 & \\
\hline 39 & Cobitidae & HS1 & Iksookimia yongdokensis & 100 & EU670800 & - & - & \\
\hline 40 & Cobitidae & TH2 & Iksookimia yongdokensis & 99 & EU670800 & - & - & \\
\hline 41 & Pleuronectidae & $\mathrm{SJ} 3$ & Kareius bicoloratus & 100 & - & - & AP002951 & \\
\hline 42 & Clupeidae & TH3 & Konosirus punctatus & 100 & - & KC477844 & LC020951 & $\begin{array}{l}\text { Taiwan } \\
\text { AP011612 }\end{array}$ \\
\hline 43 & Clupeidae & ND3 & Konosirus punctatus & 99 & - & KC477844 & LC020951 & $\begin{array}{l}\text { Taiwan } \\
\text { AP011612 }\end{array}$ \\
\hline 44 & Centrarchidae & TH4 & Lepomis macrochirus & 100 & - & JN389795 & AP005993 & $\begin{array}{l}\text { USA } \\
\text { KP013118 }\end{array}$ \\
\hline 45 & Amblycipitidae & SJ1 & Liobagrus sp. & 97 & KR075136 & KX096605 & AP012015 & \\
\hline 46 & Cyprinidae & SJ2 & Microphysogobio koreensis & 100 & FJ515920 & - & - & \\
\hline 47 & Cyprinidae & $\mathrm{SJ} 1$ & Microphysogobio yaluensis & 99 & KR075133 & - & AP012073 & \\
\hline 48 & Centrarchidae & ND1 & Micropterus salmoides & 100 & - & HQ391896 & LC069536 & $\begin{array}{l}\text { USA } \\
\text { DQ536425 }\end{array}$ \\
\hline 49 & Centrarchidae & HS1 & Micropterus salmoides & 99 & - & HQ391896 & LC069536 & $\begin{array}{l}\text { USA } \\
\text { DQ536425 }\end{array}$ \\
\hline 50 & Cobitidae & $\mathrm{SJ} 1$ & Misgurnus anguillicaudatus & 100 & - & KC762740 & - & \\
\hline 51 & Cobitidae & TH1 & Misgurnus anguillicaudatus & 99 & - & KC762740 & - & \\
\hline 52 & Cobitidae & $\mathrm{SJ} 2$ & Misgurnus anguillicaudatus & 99 & EU670804 & - & - & \\
\hline
\end{tabular}




\begin{tabular}{|c|c|c|c|c|c|c|c|}
\hline Cobitidae & HS1 & Misgurnus anguillicaudatus & 99 & - & - & LC385093 & \\
\hline Cobitidae & HS1 & Misgurnus bipartitus & 100 & - & KF562047 & LC091592 & \\
\hline Cobitidae & TH3 & Misgurnus mizolepis & 100 & AP017654 & - & - & \\
\hline Cobitidae & HS3 & Misgurnus mizolepis & 99 & AP017654 & - & - & \\
\hline Mugilidae & HS1 & Mugil cephalus & 100 & - & KF374974 & LC278014 & \\
\hline Gobiidae & TH3 & Mugilogobius abei & 100 & KM030465 & - & LC421743 & $\begin{array}{c}\text { Taiwan } \\
\text { KF128984 }\end{array}$ \\
\hline Cyprinidae & TH1 & Nipponocypris koreanus & 100 & - & KJ427719 & - & \\
\hline Cyprinidae & HS1 & Nipponocypris temminckii & 100 & - & - & AP012116 & \\
\hline Cobitidae & TH1 & Niwaella multifasciata & 100 & EU670807 & - & LC146133 & \\
\hline Cobitidae & HS1 & Niwaella sp. (unidentified) & 96 & EU670807 & - & LC146133 & \\
\hline Odontobutidae & SJ1 & Odontobutis interrupta & 100 & KR364945 & - & - & \\
\hline Odontobutidae & HS1 & Odontobutis platycephala & 100 & KM030426 & - & - & \\
\hline Odontobutidae & $\mathrm{SJ} 2$ & Odontobutis platycephala & 99 & KM030426 & & & \\
\hline Cyprinidae & HS1 & Opsariichthys sp. (unidentified) & 96 & - & - & AB218897 & \\
\hline Cyprinidae & TH3 & Opsariichthys uncirostris & 99 & - & - & AB218897 & \\
\hline Cobitidae & TH4 & Paramisgurnus dabryanus & 100 & - & KM186182 & LC146125 & \\
\hline Cobitidae & HS1 & Paramisgurnus dabryanus & 100 & - & KJ699181 & LC146125 & \\
\hline Cyprinidae & $\mathrm{SJ} 2$ & Phoxinus oxycephalus & 99 & MK208924 & - & AB626852 & \\
\hline Cyprinidae & $\mathrm{SJ} 3$ & Phoxinus oxycephalus & 99 & MK208924 & - & AB626852 & \\
\hline Cyprinidae & TH3 & Phoxinus semotilus & 100 & KT748874 & - & - & \\
\hline Mugilidae & TH3 & Planiliza affinis & 100 & - & KM925142 & LC277843 & \\
\hline Mugilidae & $\mathrm{SJ} 2$ & Planiliza haematocheila & 100 & - & KJ622047 & LC021099 & \\
\hline Mugilidae & HS4 & Planiliza haematocheila & 100 & - & KJ622047 & LC021099 & \\
\hline Bagridae & SJ1 & Pseudobagrus koreanus & 100 & KT601095 & - & - & \\
\hline Bagridae & ND1 & Pseudobagrus ussuriensis & 100 & - & $\mathrm{KC} 188782$ & - & \\
\hline Bagridae & ND2 & Pseudobagrus ussuriensis & 99 & - & KC188782 & - & \\
\hline Cyprinidae & ND2 & Pseudogobio esocinus & 100 & - & - & LC340042 & \\
\hline Cyprinidae & ND1 & Pseudogobio esocinus & 99 & - & - & LC340042 & \\
\hline Cyprinidae & ND3 & Pseudogobio vaillanti & 100 & - & KU314695 & LC146041 & \\
\hline Cyprinidae & $\mathrm{SJ} 2$ & Pseudogobio vaillanti & 99 & - & KU314695 & LC146041 & \\
\hline Gobiidae & TH3 & Pseudogobius masago & 100 & KM030467 & - & LC049791 & \\
\hline
\end{tabular}




\begin{tabular}{|c|c|c|c|c|c|c|c|}
\hline Cyprinidae & TH1 & Pungtungia herzi & 99 & KF006339 & - & AB239598 & \\
\hline Cyprinidae & $\mathrm{SJ} 1$ & Pungtungia sp. & 97 & KF006339 & - & AB239598 & \\
\hline Cyprinidae & TH1 & Pungtungia sp. (unidentified) & 96 & KF006339 & - & AB239598 & \\
\hline Gobiidae & HS1 & Rhinogobius brunneus & 100 & KT601096 & - & & \\
\hline Gobiidae & ND2 & Rhinogobius brunneus & 100 & & & LC049760 & \\
\hline Gobiidae & ND1 & Rhinogobius giurinus & 100 & KM030475 & KP892753 & LC049748 & \\
\hline Cyprinidae & $\mathrm{SJ} 2$ & Rhodeus suigensis & 100 & EF483934 & - & - & \\
\hline Cyprinidae & $\mathrm{SJ} 1$ & Rhodeus uyekii & 100 & EF483937 & - & - & \\
\hline Cyprinidae & HS1 & Rhynchocypris lagowskii & 99 & - & KJ641843 & - & \\
\hline Cyprinidae & TH3 & Rhynchocypris lagowskii & 99 & & KJ641843 & & \\
\hline Cyprinidae & TH4 & Rhynchocypris lagowskii & 99 & & KJ641843 & & \\
\hline Cyprinidae & $\mathrm{SJ} 2$ & Rhynchocypris oxycephalus & 99 & - & - & LC193377 & \\
\hline Cyprinidae & $\mathrm{SJ} 3$ & Rhynchocypris oxycephalus & 99 & & & LC193377 & \\
\hline Cyprinidae & HS4 & Rhynchocypris sp. & 98 & & & LC193377 & \\
\hline Cyprinidae & HS2 & Sarcocheilichthys soldatovi & 100 & - & - & LC146036 & \\
\hline Cyprinidae & HS2 & Sarcocheilichthys sp. & 97 & KU301744 & - & AP012067 & \\
\hline Cyprinidae & ND3 & Sarcocheilichthys sp. & 97 & KU301744 & - & AP012067 & \\
\hline Cyprinidae & SJ2 & Sarcocheilichthys variegatus & 100 & KU301744 & - & AP012067 & \\
\hline Siluridae & ND1 & Silurus asotus & 100 & - & JX087351 & NC015806 & \\
\hline Siluridae & TH1 & Silurus microdorsalis & 99 & KT350610 & - & - & \\
\hline Siluridae & $\mathrm{SJ} 1$ & Silurus sp. (unidentified) & 96 & KT350610 & & & \\
\hline Sinipercidae & SJ1 & Siniperca scherzeri & 100 & - & MF966985 & - & $\begin{array}{l}\text { Taiwan } \\
\text { AP014527 }\end{array}$ \\
\hline Cyprinidae & $\mathrm{SJ} 2$ & Squalidus chankaensis & 100 & KT948082 & - & - & \\
\hline Cyprinidae & HS3 & Squalidus japonicus & 100 & & & LC277782 & \\
\hline Cyprinidae & $\mathrm{SJ} 3$ & Squalidus japonicus & 99 & & & LC277782 & \\
\hline Cyprinidae & TH3 & Squalidus japonicus coreanus & 100 & KR075134 & - & & \\
\hline Cyprinidae & HS1 & Squalidus multimaculatus & 100 & KX495606 & - & - & \\
\hline Bagridae & SJ1 & Tachysurus fulvidraco & 100 & - & KU133295 & LC193372 & \\
\hline Bagridae & ND2 & Tachysurus nitidus & 100 & - & KC822643 & - & \\
\hline Cyprinidae & SJ1 & Tanakia signifer & 99 & EF483930 & - & - & \\
\hline
\end{tabular}




\begin{tabular}{llllclll}
114 & Cyprinidae & SJ2 & Tanakia somjinensis & 99 & FJ515921 & - & - \\
115 & Cyprinidae & SJ1 & Tanakia sp.(unidentified) & 96 & FJ515921 & & \\
116 & Cyprinidae & TH2 & Tribolodon hakonensis & 100 & - & - & AB626855 \\
117 & Cyprinidae & SJ3 & Tribolodon hakonensis & 99 & - & - & AB626855 \\
118 & Gobiidae & TH4 & Tridentiger obscurus & 100 & KT601092 & MF663787 & LC193168 \\
119 & Gobiidae & SJ2 & Tridentiger radiatus & 99 & - & EU047755 & - \\
120 & Gobiidae & ND2 & Tridentiger radiatus & 99 & & & \\
121 & Gobiidae & SJ3 & Tridentiger trigonocephalus & 100 & KM030481 & & \\
122 & Gobiidae & HS4 & Tridentiger trigonocephalus & 100 & & KT282115 & LC385175 \\
123 & Cyprinidae & SJ1 & Zacco platypus & 100 & - & & LC277796 \\
124 & Cyprinidae & HS1 & Zacco platypus & 99 & & KF683339 & \\
125 & Cyprinidae & TH1 & Zacco sp. & 97 & & KF683339 & \\
\hline
\end{tabular}

2 


\section{Table 4 (on next page)}

Table 4 Shannon Index (SI) measured from four Korean rivers by eDNA metabarcoding 
Table 4 Shannon Index (SI) measured from four Korean rivers byeDNA metabarcoding

\begin{tabular}{lccccr}
\hline & $\begin{array}{c}\text { Seomjin } \\
\text { River }\end{array}$ & $\begin{array}{c}\text { Taehwa } \\
\text { River }\end{array}$ & $\begin{array}{c}\text { Hyeongsan } \\
\text { River }\end{array}$ & $\begin{array}{c}\text { Nakdong } \\
\text { River }\end{array}$ & Average \\
\hline Station 1 & 2.197 & 2.073 & 1.755 & 1.777 & 1.951 \\
Station 2 & 2.182 & 1.941 & 1.709 & 1.734 & 1.892 \\
Station 3 & 2.125 & 1.631 & 1.691 & 1.465 & 1.728 \\
Station 4 & 2.105 & 1.443 & 1.102 & 1.008 & 1.415 \\
Overall SI index & 3.48 & 3.067 & 2.954 & 2.864 & - \\
\hline
\end{tabular}

1 